\title{
AHP-TOPSIS Bütünleşik Yaklaşımıyla Deprem Riski Tabanlı İstanbul İli Kentsel Dönüşüm Öncelik Sıralaması
}

\author{
Furkan DİŞKAYA ${ }^{1}$, Şenol EMİR ${ }^{2}$
}

\begin{abstract}
Özet
Türkiye' de yllar içerisinde sosyo-ekonomik sebepler ile nüfusun büyük şehirlerde yoğunlaşması, beraberinde düzensiz, kalitesiz ve dayanıksız yapı stokunun hızlı artışı ve zaman içerisinde ekonomik ömrünü tamamlayan yapıların deprem riski nedeniyle yenilenmesi gereği, kentsel dönüşüm ihtiyacını ortaya çıkarmıştır. Özellikle deprem kuşağında yer alan İstanbul ili, nüfus yoğunluğu ve ülke ekonomisi açısından taşıdığı büyük önem sebebiyle öncelikli olarak kentsel dönüşüme gereksinim duymaktadır. Ancak son derece büyük çaplı ve yüksek maliyetlere sahip olan kentsel dönüşüm projelerinin, tüm șehir için ve eș zamanlı olarak başlatılabilmesi teknik ve ekonomik açıdan mümkün olmamaktadır. Bu durumda, yetkili kamu kurumları dönüşüme ihtiyaç duyulan ilçe ve mahallelerin deprem riski sıralamasına uygun biçimde, en acil olan mahalleden başlayacak şekilde dönüşüm planlaması yapmaktadırlar. Bu öncelik sıralaması için kullanılacak verinin doğruluğu ve değerlendirme yönteminin etkinliği analiz sonuçlarının güvenilirliği açısından son derece önem taşımaktadır. Bu çalışmada, İstanbul ili sınırlarında yer alan ilçe ve mahallelerin deprem riski baz alınarak kentsel dönüşüm önceliklerinin belirlenmesi için çok kriterli karar alma yöntemleri olan AHP ve TOPSIS metotlarının bütünleşik bir yaklaşımı kullanılmıştır. Burada temel amaç, ilçe ve mahalle bazında deprem riski altındaki yerleşim birimlerinin kentsel dönüşüm önceliklerinin belirlenmesi sayesinde kamusal ve özel projelerin planlanmasına katkı sağlamaktır.
\end{abstract}

Anahtar Kelimeler: Kentsel Dönüşüm, Çok Kriterli Karar Verme, Deprem Riski

\section{Earthquake Risk-Based Urban Transformation Priority Ranking with AHP-TOPSIS Integrated Approach: Istanbul Province Case}

\begin{abstract}
Turkey's socio-economic reasons for the concentration of the population in large cities, with irregular, poor quality and flimsy over time and the rapid increase of the building stock which has completed their economic life, the renewal of structures due to earthquake because of the risk, has revealed the need for urban transformation. Especially located in the earthquake zone, Istanbul province needs urban transformation primarily due to its population density and great importance in terms of the country's economy. But it is technically and economically impossible for urban transformation projects, which have extremely large scale and high costs, to be launched for the entire city and simultaneously. In this case, competent public institutions are planning the transformation by the risk ranking of the districts and neighborhoods where transformation is needed, starting from the most urgent neighborhood. The accuracy of the data to be used for this priority ranking and the effectiveness of the evaluation method are extremely
\end{abstract}

\footnotetext{
${ }^{1}$ Doktor Öğretim Üyesi, Beykent Üniversitesi, Mühendislik-Mimarlık Fakültesi, Endüstri Mühendisliği Bölümü, İstanbul e-posta: furkandiskaya@beykent.edu.tr ORCID No: 0000-0001-9581-6771

2 Doktor Öğretim Üyesi, İstanbul Üniversitesi, İktisat Fakültesi, Ekonometri Bölümü, İstanbul

İlgili yazar e-posta / Corresponding author e-posta: senol.emir@istanbul.edu.tr ORCID No: 0000-0002-6762-9351
} 
important for the reliability of the analysis results. In this study, an integrated approach of AHP and TOPSIS methods, which are multi-criteria decision-making methods, was used to determine the urban transformation priorities of districts and neighborhoods located on the borders of Istanbul province. The main objective here is to contribute to the planning of public and private projects by determining the urban transformation priorities of settlements at risk of earthquakes based on districts and neighborhoods.

Keywords: Urban Transformation, Multi-Criteria Decision Making, Earthquake Risk

\section{GİRIŞ}

Afet, sosyal ve ekonomik kayıplara sebep olan, yaşamı kesintiye uğratan ve ani olarak meydana gelen olay olarak tanımlanır (Varol ve Gültekin, 2016). Doğal kaynaklı ve sadece tahmini şiddeti bilinen deprem afeti, meydana getirebileceği yüksek zarar riski nedeniyle çok disiplinli bilimsel yaklaşımlar ile ele alınması gereken toplumsal bir sorundur. Bu sorun, insanların yaşamları süresince her an karşılaşabileceği, sosyal, psikolojik ve ekonomik yaşamı doğrudan etkileyen bir durum olması sebebiyle, toplumun tüm birimleri ile planlı ve programlı bir biçimde hazırlıklı olunması için ülke yönetimleri tarafından ilk sırada değerlendirilmelidir (Yılmaz, 2003).

Türkiye önemli bir deprem kuşağında yer alması itibariyle her an deprem tehlikesi ile karşı kaşıya kalmaktadır. Özellikle nüfus yoğunluğunun endüstriyel topluma geçiş ile birlikte büyük şehirlerde artışı ve beraberinde meydana gelen düzensiz ve kalitesiz yapılaşma, deprem riskinin öncelikli dikkate alınması gereken bir problem olduğunu gözler önüne sermiștir. Türkiye 1992 Erzincan, 1999 Marmara ve 2011 Van depremlerinde depreme karşı dayanıksız yapılaşma sebebiyle yakın zamanda büyük bedeller ödemiştir. Depremler sonrasında yapılan çalışmalar ile 1997 yılında Afet Bölgelerinde Yapılacak Yapılar Hakkında Yönetmelik yayınlanmış ve 1998 yılında yürürlüğe girmiștir. 2007 yılında güncellenerek Deprem Bölgelerinde Yapılacak Binalar Hakkında Yönetmelik olarak yürürlüğe girmiștir. Mevcut yapıların deprem performanslarını sismik olarak değerlendirmek ve yeni yapıların hangi teknik özelliklere göre yapılması gerektiğini içeren bu yönetmeliklere ek olarak, 4708 sayılı Yapı Denetimi Hakkında Kanun 2001 yılında yürürlüğe girmiş ve 2010 yılında tüm ülkede uygulanmaya başlamıştır.

Afet riski taşıyan bölge ve alanların belirlenerek yenilenmesi olarak tanımlanan kentsel dönüşüm ile ilgili kanun ise 2012 yılında yürürlüğe giren 6306 sayılı Afet Riski Altındaki Alanların Dönüştürülmesi kanunudur. Bu kanun ile riskli alanlar ve riskli yapıların tespiti, planlaması, yıkılması ve dönüşüme tabi olan taşınmazların tespiti ve hak sahipleri ile yapılacak tüm işlemlerin düzenlenmesi amaçlanmıştır. Bu düzenlemeler ile kentsel dönüşüm uygulamaları ülke çapında başlatılmış ve depreme dayanıksız yapıların dönüşümünün önü açılmıştır (Tümtürk ve Tümtürk, 2020).

Eskimiş, sağlıksız yaşam şartlarına sahip ve günün sosyal ve ekonomik ihtiyaçlarına cevap veremeyen yaşam alanlarının ekonomik, sosyal, fiziksel ve çevresel faktörler dikkate alınarak yenilenmesi olarak tanımlanan kentsel dönüşüm İstanbul gibi büyük kentler için oldukça hayati bir öneme sahiptir (Roberts ve Sykes, 2000). Fakat kentsel dönüşüm projeleri, hukuki, ekonomik ve sosyolojik birçok sorun barındıran son derece büyük ölçekli ve karmaşık inşaat projeleridir. Kentsel dönüşüm projelerini uygulayan kuruluşlar her projede farklı türde sorunlar ile karşılaşabilmektedirler. İstanbul gibi yapı stokunun büyük bir bölümünün yenilenmesine ihtiyaç duyulan büyük şehirlerde, alan bazında şehrin her bölgesinde topyekûn olarak eş zamanlı kentsel dönüşüm projelerinin başlatılması politik, teknik ve sosyo-ekonomik açıdan mümkün değildir. $\mathrm{Bu}$ şekilde büyük çaplı bir dönüşüm faaliyeti olması durumunda, vatandaşlar tarafından kullanımda olan evlerin yıkılması ile ortaya çıkacak muazzam konut ihtiyacı kısa vadede karşılanamayacak ve büyük mağduriyetlere sebep olacaktır. Bu durum proje uygulamasını gerçekleștiren kamu kurumlarının yönetsel kapasitesini aşacağı için projelerin uygun kurallara göre belirlenmiş bir sıraya göre yürütülmesi gerekecektir. İlçe bazında yapılacak bir sıralama 
sadece mevcut durum hakkında bilgi niteliğinde olacaktır. Ancak ilçe ve mahalle bazında hazırlanacak bir kentsel dönüşüm sıralaması, projelerin kamu kurumları tarafından yönetilebilir olmasını sağlayacaktır. Bu sebeple devlet kurumları, kentsel dönüşüm uygulamalarını en riskli bölgelerden başlayarak sırayla daha az riskli bölgelere doğru bir sıralamayla yürütmek durumundadırlar (Alaybeyoğlu vd., 2016).

Günümüzde kentsel dönüşüm, yaşanabilir, refah düzeyi yüksek ve sürdürülebilir kalkınmayı amaçlayan, mal ve hizmetlere en uygun şekilde erişilebilir, katılımcı ve yönetilebilir sosyoekonomik standartlarda, kent estetiğinin dikkate alındığı siyasal, yönetsel, sosyal, kültürel ve mekânsal uygulamalardır (Sadioğlu ve Ergönül, 2020). Ancak, yüksek seviyede afet riski altında bulunan İstanbul gibi büyük kentler için öncelikli amaç can ve mal kaybının önüne geçmek olmaktadır. Çünkü ortaya çıabilecek beklenen deprem afeti, çok yüksek can ve mal kaybına sebep olacağı gibi, ülke ekonomisi için de büyük bir yıkım meydana getirecektir. Dolayısıyla İstanbul ili için kentsel dönüşüm projeleri en uygun öncelik sıralaması ile ivedilikle uygulanmalıdır.

Literatür incelendiğinde, afet riskine dayalı kentsel dönüşüm önceliklerinin belirlenmesi kapsamında hazırlanmış az sayıda akademik çalışmaya ulaşılmıştır. İstanbul ili kapsamında ve ÇKKA (Çok Kriterli Karar Alma) yöntemleri kullanılarak deprem riski önceliklerine göre kentsel dönüşüm öncelik sıralaması yapılmış herhangi bir uygulamaya ulaşılamamıștır. Bu çalışmada, İstanbul ili için deprem riski kriterleri göz önüne alınarak, ÇKKA yöntemleri olan AHP (Analitik Hiyerarşi Prosesi) ve TOPSIS (Technique For Order Preference By Similarity To An Ideal Solution) teknikleri ile ilçe ve mahalle bazında kentsel dönüşüm öncelik sıralaması oluşturulmuştur. AHP yöntemi ile kentsel dönüşüm için öncelik kriterlerinin ağırlıkları belirlenmiş ve daha sonra TOPSIS yöntemi ile İstanbul ilindeki 39 ilçe ve 971 mahalle için öncelik sıralaması yapılmıştır. Uygulama verileri, mevcut durum için güncel olarak İstanbul Büyükşehir Belediyesi (İBB) Deprem ve Zemin İnceleme Müdürlüğü (DEZIM) bünyesinde İstanbul'un her ilçesi için hazırlanan "İstanbul İli Olası Deprem Kayıp Tahminleri Kitapçı̆̆ı" 'ndan, karar alma kriterleri ise yine DEZIM kurumunun uzman ekibinden elde edilmiştir. Çalışma için kullanılan veriler, olası 7.5 büyüklügünde bir deprem senaryosu kullanılarak ve deterministik yaklaşım temel alınarak uzmanlar tarafından oluşturulmuştur. Kurumda yer alan jeoloji, jeofizik ve inşaat mühendislerinden oluşan sekiz kişilik ekipten, uygulama kriterleri hakkında ikili karşılaştırma yoluyla önem derecesi değerlendirme bilgileri alınmıștır. Elde edilen veriler ıșığında AHP yöntemi ile kriter ağırlıkları belirlenmiş ve daha sonra bu ağırlıklar ve ilçe-mahalle verileri kullanılarak TOPSIS yöntemiyle sıralama işlemi yapılmıştır.

Kentsel dönüşüm projelerinin sürdürülebilirliği ile ilgili yapılan çalışmada, Monte Carlo simülasyon yöntemi ile bulanık mantık modeli entegre edilmiştir. Ölçüm kriterlerinin belirlenmesinin ardından anket çalışması yapılmış ve ölçüm kriterleri belirlenmiştir. Sonraki aşamada ise, geliştirilen model için performans verileri toplanmış ve kriterlere önem derecesi ağırlıkları atanmıştır. Çevresel, sosyal, ekonomik ve teknik gelişim olmak üzere dört adet parametre ortaya çıkarılmış ve bulanık mantık modeli oluşturulmuştur. Çalışma kentsel dönüşüm projeleri üzerinde test edilmiş ve proje sürdürülebilirliği açısından bir karar destek sistemine ulaşılmıştır (Peng vd., 2015). Afet riski altındaki yapıların tespit edilmesi ve risk önceliklerine göre mevcut binaların bölgesel dağılımlarının belirlenmesi amacıyla yapılan çalışmada, performans sıralaması yöntemi kullanılmıştır. Harita üzerinde rastgele bir bölge kurgulanmış ve bu bölgedeki yapılar için yönetmeliğe uygun olarak performans puanları hesaplanmıștır. Örnek bölgede yer alan yapılar için performans puanlarına göre sıralama yapılarak deprem risklerine göre dağılımları incelenmiștir (Gürbüz ve Tekin, 2015).

Kentsel dönüşüm öncelik sıralaması için Bulanık Mantık yöntemi kullanılan bir çalışmada, örnek bir karar destek sistemi tanıtılmıştır. Bu çalışmada, ilk olarak kentsel dönüşüm alanlarının belirlenebilmesi için dikkate alınacak parametreler uzmanlarla mülakat yapılarak belirlenmiş ve 
yapay sinir ağları tekniği ile kurallar oluşturulmuştur. Kurulan sistem örnek mahalleler üzerinde uygulanarak öncelik sıralamaları elde edilmiştir (Alaybeyoğlu vd., 2016). İstanbul için kentsel dönüşüm projelerinin önceliklerinin belirlendiği çalışmada, karar problemlerinde karar vericilerin tereddütte kaldıkları durumlarda kullanılan HFLTS (Hesitant Fuzzy Linguistic Term Set) tabanlı bir bulanık TOPSIS yöntemi yaklaşımı kullanılmıștır. İstanbul ili kapsamında gerçekleștirilen çalışmada, dört farklı kentsel dönüşüm sistemi alternatifi önceliklendirilmiş ve duyarlılık analizi ile sonuçlar değerlendirilmiştir (Oztaysi vd., 2016).

Sürdürülebilir kentsel dönüşüm için bir model önerisinin sunulduğu çalışmada, mimarlık, inşaat ve altyapı sektöründe yer alan 323 personelin katılımı ile yapılan anket çalışması sonucu kentsel dönüşüm projelerinin ekonomik, sosyal ve çevresel boyutları faktör analizi ile farklı faktörlere bölünmüştür. Bu faktörler AHP yöntemi kullanılarak ağırlıklandırılmıştır. Buna göre, ulaşım ve erişilebilirlik \%10, sosyal hayatı destekleme $\% 20$, dezavantajlı grupların korunumu \%9, çevresel yapı kalitesi \%20, ticari ve ekonomik firsatlar \%12 ve çevre ve kaynakların korunması ve çevre faktörü \%29 olmak üzere önem derecesine sahip olmuştur (Yıldız vd.,2017). AHP-TOPSIS yöntemleri ve Coğrafi Bilgi Sistemleri (CBS) kullanılarak gerçekleştirilen bir çalışmada, askeri birliklerin mühimmat ihtiyaçlarının karşılanması amacıyla bir dağıtım ağı tasarımı problemi çok amaçlı matematiksel modelleme oluşturularak çözümlenmiştir. Çeşitli risk kriterleri dikkate alınarak ana, bölgesel ve yerel depoların konumlarının ve servis atamalarını belirlemek amacıyla uygulanan araştırmada, AHP risk kriter ağırlıklandırılması ve TOPSIS ise risk puanlarının hesaplanması için kullanılmıştır. CBS analizi ise, konumsal kriterlere dayalı olarak harita katmanlarını kullanarak potansiyel depo konumlarının belirlenmesi için kullanılmıştır (Akgün ve Erdal, 2019).

AHP-TOPSIS tabanlı bütünleşik bir yaklaşımın kullanıldığı bir çalışmada, çoklu mahalle yenileme projelerinin göreceli olarak performansı değerlendirilmiştir. Çin'in Nanjing kentinde yapılan vaka çalışmasına göre her mahalle için sürdürülebilir bir kentsel dönüşüm modeli hedeflenmiştir. Bulgulara göre, kamu ve özel sektörden sürdürülebilir finansmanın sağlanması, çok ilkeli aracı sisteminin oluşturulması ve çok programlı yönetim önlemlerinin uygulanması performans iyileştirilmesi için önerilmiştir (Zhu vd., 2019). AHP temelli GİA (Gri İlişkisel Analiz) yönteminin kullanıldığı bir çalışmada, satın alınacak en uygun konutun seçimi için birden fazla seçenek ve ölçüte göre bir karar modeli oluşturulmuştur. İlk aşamada konut seçeneklerinin değerlendirilmesi amacıyla ölçütler ortaya konulmuştur. Tespit edilmiş ölçütlerin ağırlıklarının belirlenmesi için AHP yöntemi, konut seçenekleri sıralaması için ise GİA yöntemi uygulanmıştır (İpek ve Şahin, 2019).

AHP temelli TOPSIS yönteminin kullanıldığı bir çalışmada, birçok farklı seçenek ve kriter içeren konutlar için seçim yapılmıştır. AHP yöntemi ile ölçütlere ağırlıklar verilmiş ve TOPSIS yöntemiyle seçenekler sıralanmıştır. Böylece uygun seçimi için bir karar modeli oluşturulmuştur (Alkan ve Durduran, 2020). Bulanık DEMATEL yöntemin uygulandığı bir çalışmada, Çin' de sürdürülebilir eski yerleşim bölgelerinin yenilenmesi üzerindeki kritik engeller arasındaki ilişkilerin etkileri incelenmiştir. Bu amaçla, literatür taraması ve uzman görüşleri ile 19 adet engel belirlenmiştir. Engeller arasındaki ilişkiler Bulanık DEMATEL yöntemi ile araştırılmıştır. Sonuç olarak, sürdürülebilir olmayan mahalle yenilemesinin temel nedeni olarak etkili ve destekleyici kamu politikalarının eksikliği belirlenmiştir (Zhu vd., 2020).

Yapay sinir ağları ve AHP-TOPSIS tabanlı bütünleşik yöntemlerin kullanıldığı bir çalışmada, deprem riski değerlendirmesini iyileştirmek için Endonezya'nın Aceh kentinde bir uygulama gerçekleştirilmiştir. Yapay sinir ağlarının çapraz doğrulaması ve AHP-TOPSIS bütünleşik yaklaşımının hibrit bir model olarak uygulandığı çalışmada, olası deprem senaryolarına göre bir sonraki risk durumu değerlendirmesi yapılmıştır. Ayrıca, sosyal ve yapısal faktörlere dayalı olarak bir kırılganlık haritası oluşturularak nüfus ve risk altındaki alanlar hesaplanmıştır (Jena vd., 2020). Coğrafi Bilgi Sistemlerine dayalı deprem risk değerlendirmesi içeren bir çalışmada, 
Bulanık AHP ve Yapay Sinir Ağları yöntemleri entegre olarak kullanılmıștır. Sismik hareketliliğin yoğun olduğu İran Sanandaj bölgesi için gerçekleştirilen çalışmaya göre, çevresel, demografik ve fiziksel kriterlere göre deprem risk kırılganlığının boyutu değerlendirilmiştir. Yapay Sinir Ağları ve Bulanık AHP entegre olarak uygulandığı çalışmada, beş güvenlik açığı sınıfı oluşturan bir deprem risk değerlendirme haritası elde edilmiştir (Yariyan vd., 2020). Derin öğrenme (deep learning) ve jeo uzamsal analiz (geospatial analysis) kullanılan bir çalışmada, Hindistan' da deprem riski olasılığı değerlendirmesi için evrişimsel sinir ağı olan CNN (Convolutional Neural Network) modeli geliştirilmiştir. Bulunan model AHP yöntemi kullanılarak belirlenmiş dokuz kriter için güvenlik riskleri değerlendirmesi yapılmıștır. Son olarak tehlike, kırılganlık ve başa çıkma kapasitesi ile bir deprem risk haritası oluşturulmuştur (Jena vd., 2021).

\section{KENTSEL DÖNÜŞÜM KAVRAMI}

Kentsel dönüşüm birçok farklı amaçla gerçekleştirilen çok boyutlu bir kavramdır. Kentsel bozulma süreçlerinin daha iyi anlaşılması ihtiyacından doğan ve dönüşüm sonunda elde edilebilecek sonuçların üzerinde uzlaşmadır (Lichfield, 1992). Diğer bir tanıma göre, kentsel çöküntü alanlarında yoğunlaşmış sorunları eş zamanlı olarak çözümleyebilmek amacıyla ortaya çıkarılan yeni yol ve yöntemler bütünüdür (Donnison, 1993). Kentsel dönüşüm, zamanla ortaya çıkan kentsel problemlerin çözülmesi ve değişime maruz kalmış bölgenin fiziksel, ekonomik, çevresel ve sosyal koşullarında kalıcı bir iyileștirme sağlanmasını hedefleyen entegre ve kapsamlı eylem ve vizyon bütünüdür (Roberts ve Sykes, 2017).

Kentsel dönüşüm kavramı 1940’lı yıllarla birlikte farklı biçimdeki kentsel alan uygulamalarının tamamını kapsayacak bir üst kavram olarak kullanılmaya başlanmıştır. Bu sebeple kentsel dönüşüm, kentsel yeniden canlandırma (urban rehabilitation, urban revitalization), yeniden inşa(reconstruction), yeniden üretim(regeneration), kentsel yenileme (urban renovation, urban renewal), kentsel yeniden geliştirme (urban redevelopment), kentsel tazeleme (urban refurbishment) ve kentsel koruma (urban conservation) gibi birçok isimle ifade edilen kentsel müdahale şeklini bünyesinde barındırmaktadır (Keleş, 2004).

Kentsel dönüşüm süreci genel anlamda ön hazırlık, planlama ve dönüşüm olarak üç temel aşamadan meydana gelir. Ön hazırlık aşamasında, dönüşüm alanının özellikleri ve detayları hakkında yapılan ayrıntılı bir analiz sonucu yöntem ve strateji belirlenir. Planlama aşamasında, belirlenmiş yöntem ve strateji kapsamında uzun vadeli hedefler belirlenerek eylem planı hazırlanır. Dönüşüm aşaması ise uygulamanın gerçekleștirildiği, denetlendiği, avantaj ve dezavantajların belirlendiği ve gerekli hallerde revizyonların sağlandığı yüksek seviyede riskli aşamadır (Ataöv ve Osmay, 2007).

Kentsel dönüşüm kavramı sadece fiziksel alanlarda yaşanan değişimi değil, gerçekleştiği bölgenin kültürel, sosyal, ekonomik ve yönetsel yapısının, projenin amaçları ile birlikte değerlendirilmesi gereken bir süreçtir. Günümüz şartlarında kentsel dönüşüm, çöküntü sürecindeki dönüşüme konu olan alanda gerçekleşen iyileştirme ve standartların yükseltilmesi hedefleri doğrultusunda kullanılıyor olsa da, sosyo-ekonomik, kültürel ve yönetsel boyutuyla çok yönlü bir sistemdir. Fiziksel boyut, dönüşümün gerçekleştiği alan içindeki tüm alt ve üst yapı alanlarını, potansiyellerini ve problemlerini içeren kısımda incelenir. Fiziksel alana müdahale, kentsel dönüşüm projelerinin ilk etkilerinin ortaya çıktığı süreci olduğu için planlama aşamasında dikkatlice belirlenmelidir. Sosyo-ekonomik yönden gelişmiş standartları olan toplumlar, bireysel yaşamlarına, gelecek nesiller için ve çevrelerine yüksek kalitede ve sağlıklı kent ortamları oluşturmak istemektedirler. Bu bağlamda gelişmiş toplumsal standartlara sahip yaşam ortamları meydana getirmek, yerel ve merkezi yönetimlerin temel amaçları içerisinde yer almaktadır (Roberts ve Skyes, 2000). Bu sebeplerle dönüşümün gerçekleştiği kent alanlarında yer alan nüfusun ekonomik seviyesi, kültürel yapısı ve yaşam tarzı detaylı olarak incelenerek bölgeye 
uygun ve sürdürülebilir projeler gerçekleștirilmelidir. Kentsel dönüşüm sonrasında yaşam alanlarının önceki durumuna uyumlu bir yapı meydana gelmişse, proje zamanla bölge halkı ile birlikte gelişimine devam edecektir. Dolayısıyla, fiziksel değişimin sosyal yapı ile uyumlu hale getirilmesi sağlıklı ve verimli bir dönüşüm anlamına gelecektir. Ayrıca bölgenin dönüşüm ile beraber ekonomik bir güç ile gelişim ivmesi yakalaması için, yüksek gelir grubu sosyal sınıfın bu alanlara çekilmesi ve toprak değerinin yükseltilmesi amacıyla çalışmalar yapmak faydalı olacaktır (Alterman ve Cars, 1991).

Kentsel dönüşüm ilk kez kavram olarak II. Dünya Savaşı sonrasında yıkıntıya dönen Avrupa şehirlerindeki sosyal ve ekonomik anlamda çöküntü yaşamış kentsel alanların yeniden inşa edilmesi için gerçekleştirilen çalışmaları tanımlamak için kullanılmıştır. Toplumsal bozulma ve fiziksel bozulma arasındaki ilişkinin ön plana çıktığı 1960'lı ve 1970'li yıllarda, yoksul mahalleler ile kent merkezlerinin yenilenmesi ve iyileștirilmesi uygulamaları şeklinde birçok kentsel dönüşüm projeleri gerçekleştirilmiştir (Akkar, 2006). 1970'li yılların sonlarından itibaren sanayi alanlarının kent merkezlerinin dışında yer alması gerektiği düşüncesi sonucu eski sanayi alanları kentlere yeniden kazandırılmaya başlanmıştır.

Kentsel dönüşüm kavramının büyük değişimi 1980'li yıllardan sonra başlamıştır. Önceki yıllarda kamu yararı amacıyla gerçekleştirilen dönüşüm uygulamaları yerini kent yatırımcılarının kârının ön plana alındığı ve bu kapsamda yeni cazibe merkezlerinin üretildiği bir döneme bırakmıştır. 1990'lı yıllar birçok farklı sektörün ve aktörün işbirliklerine dayanan, kamu ve özel sektörün katılımları dışında farklı kesimlerin de süreçlere müdahil oldukları bir süreç başlamıştır (Akkar, 2006).

Günümüz şartlarında kentsel dönüşüm, ülkelerin veya şehirlerin fiziksel, sosyal ve ekonomik yapılarına göre farklılıklar göstermektedir. Son yıllarda etkisi yoğun bir şekilde görülen küresel iklim değiş̧ikliği ve çevresel sorunlar, birçok gelişmiş ülkenin düşük karbon salınımlı ve iklim dostu dönüşüm teknolojilerini kullanmalarına neden olmuştur. Bu kapsamda son yıllarda pek çok bilimsel araştırma ve projeler hayata geçirilmiş, sürdürülebilir kentsel dönüşüm kavramı ön plana gelmiştir (Balaban, 2013).

Kentsel dönüşümün gelişimi incelendiğinde, kamusal alanları arttırmak ve sürdürülebilirliğinin sağlanması için başladığı ve günümüze ulaştığı görülmektedir. Bu anlamda kentsel dönüşümün temel amaçları:

- Toplumsal yaşam kalitesini ve refahı arttıracak ekonomik kalkınma stratejilerini ortaya koymak,

- Kentin toplumsal sorunlarına çözüm bulabilmek için kentin fiziksel durumunu en etkin şekilde kullanabilecek yöntemleri geliştirmek,

- Kentin yerleşim biçimini oluşturan unsurların fiziksel anlamda değişim ihtiyacına çözüm sunmak,

- Kentsel alanların etkin ve verimli bir şekilde kullanımını sağlamak,

- Kentsel yönetim politikalarının oluşturulması

olarak ifade edilebilir (Roberts ve Sykes, 2000).

Tablo 1, kentsel dönüşümün yıllar içerisindeki uygulanan farklı politikalar kapsamında 1950 'lerden günümüze gelişim sürecini vermektedir. 
Tablo 1. Kentsel dönüşümün gelişim süreci

\begin{tabular}{|c|c|c|c|c|c|c|}
\hline DÖNEM & 1950'ler & 1960'lar & 1970'ler & 1980'ler & 1990'lar & 2000'ler \\
\hline Politikalar & $\begin{array}{l}\text { Yeniden İnşa } \\
\text { (Reconstruction) }\end{array}$ & $\begin{array}{l}\text { Yeniden } \\
\text { Canlandırma } \\
\text { (Revitalization) }\end{array}$ & $\begin{array}{l}\text { Yenileme } \\
\text { (Renewal) }\end{array}$ & $\begin{array}{l}\text { Yeniden } \\
\text { Geliştirme } \\
\text { (Redevelopment) }\end{array}$ & $\begin{array}{l}\text { Yeniden } \\
\text { Üretim } \\
\text { (Regeneration) }\end{array}$ & $\begin{array}{l}\text { Yenilemede } \\
\text { Reform } \\
\text { (Re-Renewal) }\end{array}$ \\
\hline $\begin{array}{l}\text { Temel } \\
\text { Strateji ve } \\
\text { Eğilim }\end{array}$ & $\begin{array}{l}\text { Kentlerin } \\
\text { eskiyen ve } \\
\text { köhneleşen } \\
\text { alanlarının } \\
\text { master plan } \\
\text { dâhilinde } \\
\text { yeniden inşa ve } \\
\text { genişletilmesi, } \\
\text { banliyölerin } \\
\text { büyümesi }\end{array}$ & $\begin{array}{l}1950 \text { 'ler } \\
\text { döneminin } \\
\text { devamı, } \\
\text { banliyö ve kent } \\
\text { çeperlerinde } \\
\text { büyüme, ilk } \\
\text { iyileştirme } \\
\text { çalışmaları }\end{array}$ & $\begin{array}{l}\text { Kentin ana } \\
\text { bölgelerinde } \\
\text { yenileme ve } \\
\text { mahalle } \\
\text { projelerinde } \\
\text { yoğunlaşma }\end{array}$ & $\begin{array}{l}\text { Birçok temel } \\
\text { gelişim ve } \\
\text { yeniden gelişim } \\
\text { projeleri, kent } \\
\text { dişı projeler }\end{array}$ & $\begin{array}{l}\text { Politika ve } \\
\text { uygulamalarda } \\
\text { daha kapsamlı } \\
\text { yaklaşımlar, } \\
\text { bütünleşmiş } \\
\text { iyileştirme } \\
\text { yaklaşımları }\end{array}$ & $\begin{array}{l}\text { Büyüme } \\
\text { alanlarında } \\
\text { bazı } \\
\text { faaliyetlerin } \\
\text { kısıtlanması }\end{array}$ \\
\hline $\begin{array}{l}\text { Temel } \\
\text { Aktörler } \\
\text { ve } \\
\text { Taraflar }\end{array}$ & $\begin{array}{l}\text { Merkezi ve yerel } \\
\text { yönetimler, özel } \\
\text { sektör ve } \\
\text { yükleniciler }\end{array}$ & $\begin{array}{l}\text { Kamu ve özel } \\
\text { sektör arasında } \\
\text { dengeli } \\
\text { yaklaşım }\end{array}$ & $\begin{array}{l}\text { Özel sektörün } \\
\text { artan rolü ve } \\
\text { yerel } \\
\text { yönetimlerin } \\
\text { odaktan } \\
\text { uzaklaşması }\end{array}$ & $\begin{array}{l}\text { Özel sektör ve } \\
\text { artan } \\
\text { uzmanlıklara } \\
\text { önem verilmesi, } \\
\text { ortaklık } \\
\text { yapılarının } \\
\text { büyümesi }\end{array}$ & $\begin{array}{l}\text { Ortaklık } \\
\text { yaklaşımlarının } \\
\text { hâkimiyeti }\end{array}$ & $\begin{array}{l}\text { Özel sektör ve } \\
\text { sivil } \\
\text { çalışmalara } \\
\text { vurgu }\end{array}$ \\
\hline $\begin{array}{l}\text { Eylemin } \\
\text { Mekânsal } \\
\text { Boyutu }\end{array}$ & $\begin{array}{l}\text { Yerel ve mekân } \\
\text { düzeyinde } \\
\text { yaklaşım }\end{array}$ & $\begin{array}{l}\text { Bölgesel } \\
\text { düzeyde } \\
\text { müdahaleler }\end{array}$ & $\begin{array}{l}\text { Başlangıçta } \\
\text { bölgesel ve } \\
\text { yerel düzey, } \\
\text { sonraları } \\
\text { yerel düzeyin } \\
\text { öne çıkması }\end{array}$ & $\begin{array}{l}1980 \text { başlarında } \\
\text { mekân } \\
\text { düzeyinde } \\
\text { sonraları yerel } \\
\text { düzeyde } \\
\text { odaklanma }\end{array}$ & $\begin{array}{l}\text { Stratejik bakış } \\
\text { açısının } \\
\text { yeniden } \\
\text { sunuşu, } \\
\text { bölgesel } \\
\text { eylemlerin } \\
\text { artması }\end{array}$ & $\begin{array}{l}\text { Yerelleşme ile } \\
\text { alt bölgesel } \\
\text { çalışmalar }\end{array}$ \\
\hline $\begin{array}{l}\text { Ekonomik } \\
\text { Odak }\end{array}$ & $\begin{array}{l}\text { Düşük oranda } \\
\text { özel sektör } \\
\text { yatırımı, ağırlıklı } \\
\text { olarak kamu } \\
\text { yatırımları }\end{array}$ & $\begin{array}{l}\text { Özel sektör } \\
\text { yatırımların } \\
\text { artması } \\
\text { sonucu, } 1950 \\
\text { döneminin } \\
\text { devamı }\end{array}$ & $\begin{array}{l}\text { Kamu } \\
\text { sektöründe } \\
\text { kaynak } \\
\text { sıkıntısı ve } \\
\text { özel sektör } \\
\text { yatırımlarında } \\
\text { artış }\end{array}$ & $\begin{array}{l}\text { Özel sektör } \\
\text { hâkimiyeti ile } \\
\text { seçici kamu } \\
\text { fonları }\end{array}$ & $\begin{array}{l}\text { Kamu, özel } \\
\text { sektör ve } \\
\text { gönüllü } \\
\text { kuruluşlar } \\
\text { arasında daha } \\
\text { dengeli bir yapı }\end{array}$ & $\begin{array}{l}\text { Özel sektör } \\
\text { seçici, kamu } \\
\text { baskın }\end{array}$ \\
\hline $\begin{array}{l}\text { Sosyal } \\
\text { Kapsam }\end{array}$ & $\begin{array}{l}\text { Konut } \\
\text { iyileştirilmesi ve } \\
\text { yaşam } \\
\text { standartlarının }\end{array}$ & $\begin{array}{l}\text { Sosyal } \\
\text { imkânların ve } \\
\text { refah } \\
\text { düzeyinin } \\
\text { artması }\end{array}$ & $\begin{array}{l}\text { Toplumsal } \\
\text { temelli } \\
\text { planlama ve } \\
\text { artan yetkiler }\end{array}$ & $\begin{array}{l}\text { Seçici devlet } \\
\text { desteği ile } \\
\text { toplumun kendi } \\
\text { sorunlarına } \\
\text { çözüm sağlaması }\end{array}$ & $\begin{array}{l}\text { Toplumun } \\
\text { rolünün önem } \\
\text { kazanması }\end{array}$ & $\begin{array}{l}\text { Yerel } \\
\text { girişimler ve } \\
\text { üçüncü sektör } \\
\text { teşviki }\end{array}$ \\
\hline $\begin{array}{l}\text { Fiziksel } \\
\text { Vurgu }\end{array}$ & $\begin{array}{l}\text { İç bölgelerin yer } \\
\text { değiştirmesi ve } \\
\text { yakın çevrenin } \\
\text { gelişimi }\end{array}$ & $\begin{array}{l}\text { Mevcut } \\
\text { alanların } 1950 \\
\text { eğiliminin } \\
\text { eylemleri } \\
\text { paralelinde } \\
\text { iyileştirilmesi }\end{array}$ & $\begin{array}{l}\text { Eski yerleşim } \\
\text { alanlarının } \\
\text { geniş } \\
\text { kapsamlı } \\
\text { yenilenmesi }\end{array}$ & $\begin{array}{l}\text { Yer değiştirme } \\
\text { ve yeni } \\
\text { geliştirme, temel } \\
\text { büyük projeler }\end{array}$ & $\begin{array}{l}\text { 1980’lere göre } \\
\text { daha mütevazı } \\
\text { koruma } \\
\text { yaklaşımı }\end{array}$ & $\begin{array}{l}\text { Daha büyük } \\
\text { projeler daha } \\
\text { küçük ölçek }\end{array}$ \\
\hline $\begin{array}{l}\text { Çevresel } \\
\text { Yaklaşım }\end{array}$ & $\begin{array}{l}\text { Peyzaj ve } \\
\text { yeşillendirme } \\
\text { çalışması }\end{array}$ & $\begin{array}{l}\text { Daha seçici } \\
\text { iyileştirmeler }\end{array}$ & $\begin{array}{l}\text { Bazı yeni } \\
\text { buluşlarla } \\
\text { yapılan } \\
\text { çevresel } \\
\text { iyileştirmeler }\end{array}$ & $\begin{array}{l}\text { Daha geniş } \\
\text { kapsamlı } \\
\text { çevresel } \\
\text { yaklaşımlar }\end{array}$ & $\begin{array}{l}\text { Daha geniş } \\
\text { kapsamlı } \\
\text { çevresel } \\
\text { sürdürülebilir } \\
\text { fikirlerin } \\
\text { gelişimi }\end{array}$ & $\begin{array}{l}\text { Sürdürülebilir } \\
\text { kalkınma } \\
\text { modeli }\end{array}$ \\
\hline
\end{tabular}

Kaynak: Roberts, P., ve Sykes, H. (2000). 


\subsection{Türkiye'de Kentsel Dönüşümün Gelişimi}

Avrupa'da ilk olarak sanayi devrimi etkisiyle ortaya çıkan kentsel dönüşüm kavramı, ülkemizde ise ilk olarak Osmanlı döneminde doğal afet ve yangın bölgelerinin yeniden inşa edilmesi ile görülmüştür. Cumhuriyetin ilanı sonrasında hızlanan kentleşme hareketleri, 1950'li yıllarda sanayinin gelişimi ile birlikte kırsal alanlardan kentlere göçü başlatmıştır. Fakat konut stoklarının nüfus artışına karşı yetersiz kalması ve kentlerin kontrolsüz şekilde aşırı büyümesi, barınma ihtiyacının halk tarafından yasadışı bir şekilde bireysel olarak karşılanmasına neden olmuştur. Düzensiz ve kontrolsüz gelişen bu durum, gecekondulaşma ve işlevini yitiren kent bölgelerinin artması sonucunu doğurmuştur. Yasal yaptırımlar ile durumun önüne geçilmek istense de siyasi ve ekonomik rant sebebiyle çözüme etkin bir şekilde ulaşılamamıştır.

1980'li yıllarda, küresel ekonomik sistemin etkisiyle apartman ve site imarı hız kazanmıștır. Yeni konut yapılaşması yüksek nüfuslu büyük kentler için barınma ihtiyacına faydalı olsa da, büyük kentlere göçün devam etmesiyle mevcut yasadışı yapıların artışına engel olamamıştır. 1985 yılında yürürlüğe sokulan beşinci kalkınma planı doğrultusunda, ruhsatsız yapılar ve gecekondu alanları için altyapı hizmeti sağlanmaya ve kanuni olarak ıslahına başlanmıştır. 2000'li yıllara kadar defalarca yapılan yeni düzenlemeler ile de çarpık kentleşmenin önüne geçilememiştir. 1984 yılında devlet tarafından kurulan Toplu Konut ve Kamu Ortaklığı İdaresi Başkanlığı (TOKİ) projelerinin alt gelir grubuna yönelik olmaması ve yetersizliği, yeni ekonomik düzende belediyelerin yönetsel rollerinin değişimi ile rantın ön planda olması, konut sorunu devam eden bireylerin yine yasadışı çözümlere yönelmelerine yol açmıştır.

2000'li yıllar kentsel dönüşüm kavramının belirli stratejiler ile ele alınmaya çalışıldığı bir dönemdir. Kamunun bu dönemde yürürlüğe sunduğu sekizinci, dokuzuncu ve onuncu kalkınma planlarıyla, belediyelere kamulaștırma yetkisi verilmiş ve yeni tedbirler ele alınmıștır. Tablo 2'de ülkemizde kentsel dönüşümün yakın tarihinin dönüşüm süreci ifade edilmiştir.

Tablo 2. Türkiye'de kentsel dönüşüm süreci

\begin{tabular}{|c|c|c|}
\hline I. Dönem (1950 - 1980) & II. Dönem (1980-2000) & III. Dönem (2000 Sonrası) \\
\hline $\begin{array}{l}\text { 1. Gecekondu bölgelerinin } \\
\text { sağlıklaştırılması }\end{array}$ & $\begin{array}{l}\text { 1. Yaşam kalitesi düşmüş ve riskli } \\
\text { alanlarda kentsel yenileme }\end{array}$ & 1. Kentsel alanlarda yenileme \\
\hline $\begin{array}{l}\text { 2. Kent merkezinin çöküntü } \\
\text { alanına dönüşümü }\end{array}$ & $\begin{array}{l}\text { 2. İyileștirmeye yönelik sağlıklaştırma } \\
\text { ve islah-imar uygulamaları }\end{array}$ & 2. Apartman alanlarının iyileştirilmesi \\
\hline $\begin{array}{l}\text { 3. Gecekondu alanlarının } \\
\text { yeniden yapılandırılması }\end{array}$ & $\begin{array}{l}\text { 3.Tarihi değeri olan alanların } \\
\text { korunması ve soylulaştırılması }\end{array}$ & $\begin{array}{l}\text { 3. Yeni siteler ve kapalı yerleşim } \\
\text { alanlarının yeniden geliştirilmesi }\end{array}$ \\
\hline $\begin{array}{l}\text { 4. Bu alanlarda kentsel } \\
\text { yenileme uygulamaları }\end{array}$ & & $\begin{array}{l}\text { 4. Tarihi konut alanların } \\
\text { soylulaştırılması }\end{array}$ \\
\hline
\end{tabular}

2012 yılında yürürlüğe giren 6306 sayılı Afet Riski Altındaki Alanların Dönüştürülmesi Hakkında Kanun sonrasında 644 ve 648 sayılı Kanun Hükmünde Kararnamenin uygulamaya sokulması ile belediyelerin, il ve ilçe kamu idarelerinin yetkileri kısıtlanmış, tüm kamu arazilerinin tasarruf yetkisi Çevre ve Şehircilik Bakanlığı bünyesine devredilmiştir. Bununla birlikte yaşam kalitesi düşük, yasal olmayan ve afet riski yüksek kent alanlarının denetimi, kanunlara uygun hale getirilmesi ve sağlıklaştırılması uygulamaları hız kazanmıştır (Genç, 2008).

\section{MATERYAL ve YÖNTEM}

Analizde kullanılan veriler, İstanbul'un tüm ilçeleri için hazırlanan olası deprem kayıp tahminleri raporlarından (DEZIM,2020) alınmıștır. Bu raporlar İstanbul Büyükșehir Belediyesi Deprem Risk 
Yönetimi ve Kentsel İyileștirme Daire Başkanlığı-Deprem ve Zemin İnceleme Müdürlüğü ve Boğaziçi Üniversitesi Kandilli Rasathanesi ve Deprem Araştırma Enstitüsü Deprem Mühendisliği Ana Bilim Dalı tarafından hazırlanmıştır. Raporlarda ilçenin demografisi, jeolojik özellikleri ve bina yapısı ile ilgili detaylı bilgilere ek olarak Mw=7.5 Senaryo Depremi için yapılan tahminler yer almaktadır. Analizde ilgili senaryo durumundaki bina hasarı (çok ağır hasarlı bina sayısı, ağır hasarlı bina sayısı, orta hasarlı bina sayısı), can kaybı-yaralanma (can kaybı sayısı, ağır yaralı sayısı) ve altyapı hasarı (doğalgaz boru hasarı sayısı, içme suyu boru hasarı sayısı, atık su boru hasarı sayısı) ile ilgili tahminler kullanılmıștır. İlçelerin bina yapısı, can kaybı/yaralanma ve altyapı ile ilgili kriter değerlerinin yer aldığı tablo Ek A da sunulmuştur.

Literatür incelemesi ve DEZIM bünyesinde yer alan jeoloji, jeofizik ve inşaat mühendislerinden oluşan sekiz uzmandan mülakat yolu ile alınan görüşlerin ortalama değerleri neticesinde, problem uygulaması için kriter sayısı 8 olarak belirlenmiştir. Ayrıca, aynı uzmanlardan kriterler için ikili karşılaştırma değerlendirmesi ve kriter önem derecesi değerleri edinilmiştir. Toplam 39 ilçe ve bu ilçelerde bulunan 971 mahalle için bu değişkenlere ait veriler analizde yer almıștır.

\subsection{Analitik Hiyerarşi Prosesi Yöntemi}

AHP (Analytic Hierarchy Process) karmaşık karar problemlerinde alternatifleri belirlenen kriterlere göre sıralayarak karar vericilere yardımcı olmak amacıyla Thomas L. Saaty tarafından geliştirilmiş bir yöntemdir (Saaty,1977; Saaty,1980). AHP yönteminin çok sayıda kriter için uygulanabilme, ağır matematiksel hesaplamalar içermediğinden kolay uygulanabilir ve anlaşılabilir olma, nitel ve nicel veriler üzerinde uygulanabilme, ikili karşılaştırmaların tutarlılığının hesaplanabilmesi, karar verme problemini hiyerarşik bir yapıda gösterilebilmesi ve grup kararı alınabilmesi için uygun bir yöntem olması gibi avantajlı tarafları bulunmaktadır (Özbek,2019).Yöntemin bir diğer özelliği de karar verme probleminde kriter ağırlıklarını belirlemek amacıyla farklı çok kriterli karar alma yöntemleriyle birlikte hibrit olarak kullanılabilmesidir. Bu şekildeki hibrit kullanımlara örnek olarak AHP-TOPSIS (Arslan vd., 2020; Sharma vd., 2020; Wang vd., 2020; Jena ve Pradhan, 2020), AHP-VIKOR (Panwar vd., 2020; Ridha vd., 2020), AHP-ELECTRE (Mahmoudi vd., 2021; Vural ve Kose, 2020), AHP-PROMETHEE (Safari vd., 2020; Sanders vd., 2020) gösterilebilir.

AHP yöntemi kullanılarak kriterlerin ağırlıkları doğrudan karar verici tarafından değil de bir uzmanlar grubu tarafından belirlenebilir. Bunun için çalışmada yer alan her bir uzmandan bir kriterin diğer kriterlere göre göreceli önemini gösteren bir puan vermesi istenir. Bunun için Saaty tarafından önerilen Tablo 3' te yer alan karşılaştırma skalası kullanılır.

Tablo 3. İkili karşılaştırmada kullanılan değerler (Timor, 2010).

\begin{tabular}{|l|l|}
\hline Değerler & Önem Düzeyi \\
\hline 1 & Eşit derecede önemli \\
\hline 3 & Orta derecede önemli \\
\hline 5 & Kuvvetli derecede önemli \\
\hline 7 & Çok kuvvetli derecede önemli \\
\hline 9 & Mutlak derecede önemli \\
\hline $2,4,6,8$ & Ara değerler \\
\hline
\end{tabular}

Aşağıda bir uzman görüşüne dayalı olarak kriterlerin ağırlıklarının belirlenmesi adımları açıklamıştır (Ayçin, 2019; Papathanasiou ve Ploskas,2018; Kwiesielewicz ve Van Uden, 2004).

Adım 1: Kriterlerin Íkili Karşıllaştırma Matrisinin (X) Olușturulması

Kriterlerin birbiriyle karşılaştırılması ile ikili karşılaştırma matrisi (Denklem 1) oluşturulur. Bu matris $n$ kriterin bulunduğu bir karar problemi için $n \times n$ boyutundadır. Yapılması gereken toplam ikili karşılaştırma sayısı da $\left(n^{2}-n\right) / 2$ dir. 


$$
\boldsymbol{X}=\left[\begin{array}{ccccc}
1 & x_{12} & \cdots & \cdots & x_{1 n} \\
\frac{1}{x_{12}} & 1 & \cdots & \cdots & \cdots \\
\cdots & \cdots & 1 & \cdots & \cdots \\
\vdots & \vdots & \vdots & \vdots & \vdots \\
\frac{1}{x_{1 n}} & \cdots & \cdots & \cdots & 1
\end{array}\right]
$$

Karşılaştırma matrisinin elamanları $\left(x_{i j}\right)$ Tablo 3'de gösterilen skala baz alınarak $i$. kriterin $j$. kritere göre görece önemini göstermektedir. Bu durumda $j$. kriterin $i$. kritere göre görece önemi $x_{j i}=1 / x_{i j}$ olur. $x_{i i}$ değerleri $i$. kriterin kendisiyle karşılaştırılmasını içerdiği için 1 dir. AHP yöntemi ile grup kararı alınırken grupta yer alan uzmanların görüşlerini yansıtan ikili karşılaştırma matrislerindeki değerlerin geometrik ortalamaları alınarak tek bir görüş haline getirilir (Ayçin, 2019). İkili karşılaştırmalar subjektif olduğu için tutarsızlıklar olması mümkündür. Bu durumu sayısal olarak belirlemek için ileriki adımlarda tutarlılık hesaplaması yapilır.

\section{Adım 2: Normalize Edilmiş İkili Karşılaştırma Matrisinin ( $\left.\boldsymbol{X}^{\prime}\right)$ Bulunması}

$x_{i j}$ değerleri Denklem 2 de gösterildiği gibi kendi sütun toplamlarına bölünerek normalize edilir. Böylece normalize edilmiş matrisin her sütun toplamı 1 olur.

$$
x_{i j}^{\prime}=\frac{x_{i j}}{\sum_{i=1}^{n} x_{i j}}
$$

Adım 3: Öncelik Vektörünün (w) Hesaplanması

$\mathrm{Bu}$ adımda öncelik vektörü $\left(w=\left[w_{i}\right]_{n \times 1}\right)$ adı verilen ve her bir kriter için önem ağırlıklarını gösteren vektör hesaplanır. Öncelik vektörünün hesaplanması normalize edilmiş ikili karşılaştırma matrisindeki her bir satırın toplamının kriter sayısına bölünmesi ile hesaplanır (Denklem 3).

$$
\boldsymbol{w}_{i}=\frac{1}{n} \sum_{j=1}^{n} x_{i j}^{\prime} \quad i, j=1,2, \ldots, n
$$

\section{Adım 4: Tutarlılık Oranının (CR) Bulunması}

Tutarlılık oranının hesaplanabilmesi için Tutarlılık İndeksi (CI: Consistency Index) değerinin bulunması gerekir (Denklem 4).

$$
C I=\frac{\lambda_{\max }-n}{n-1}
$$

$\lambda_{\max }$ özdeğeri göstermektedir ve Denklem 5 de gösterildiği gibi hesaplanır. Tam tutarlılık durumunda özdeğerin kriter sayısına eşit olması gerekir (Özbek, 2019).

$$
\lambda_{\max }=\frac{1}{n} \sum_{i=1}^{n}\left[\frac{\sum_{j=1}^{n} x_{i j} w_{j}}{w_{i}}\right]
$$

Tutarlılık Oranı için gereken diğer bir değer Rastgele İndeks (RI:Random Index) değeridir. Bunun için kriter sayısına karşılık gelen $R I$ değerlerini gösteren Tablo 4 kullanılır. RI değerleri en fazla 15 kriter için hesaplanabilmektedir. 
Tablo 4. Kriter sayılarına göre RI değerleri (Alonso ve Lamata,2006).

\begin{tabular}{|l|l|l|l|l|l|l|l|l|l|l|l|l|l|l|l|}
\hline $\mathbf{n}$ & 1 & 2 & 3 & 4 & 5 & 6 & 7 & 8 & 9 & 10 & 11 & 12 & 13 & 14 & 15 \\
\hline $\mathbf{R I}$ & 0 & 0 & 0.58 & 0.89 & 1.12 & 1.24 & 1.32 & 1.41 & 1.45 & 1.49 & 1.51 & 1.53 & 1.56 & 1.57 & 1.59 \\
\hline
\end{tabular}

Tutarlılık Oranı $(C R)=C I / R I$ ile gösterilir. Bu oran 0.10 dan küçük ve eşit olduğunda ikili karşılaştırma matrisinin tutarlı olduğu ve bulunan kriter ağırlıklarının geçerli olduğu sonucuna varılır. 0.10 dan büyük değerler elde edilmesi ikili karşılaştırma matrisindeki tutarsızlığı işaret eder. Bu durumda uzmanların kriterler için yapmış olduğu ikili puanlandırmayı tekrar gözden geçirmek gerekir (Timor,2010).

\subsection{TOPSIS Yöntemi}

TOPSIS (Technique for Order Preference by Similarity to Ideal Solution) yöntemi Hwang ve Yoon (1981) tarafından geliştirilmiş ve anlaşılır olması, sonuçlarının kolay yorumlanabilmesi nedeniyle yaygın olarak kullanılan çok kriterli karar alma yöntemlerinden birisidir. TOPSIS yönteminin temelinde, ideal çözüme yakın ve aynı zamanda ideal olmayan çözüme uzak olan alternatifin seçilmesi yatmaktadır. İdeal ve ideal olmayan çözümler beklenen amacın maksimizasyon veya minimizasyon olmasına göre yöntem içindeki adımlarda hesaplanmaktadır. Bu hesaplamalar için Öklid mesafe yaklaşımı kullanılabilir (Ayçin, 2019). TOPSIS yöntemi uygulanırken takip edilmesi gereken aşamalar aşağıda yer almaktadır (Papathanasiou \& Ploskas,2018; Özdemir, 2014; Demirkol,2021; Gürkan, 2021).

Adım 1: Karar Matrisinin (X) Oluşturulması

Karar matrisi (Denklem 6) TOPSIS yöntemiyle alternatiflerin belirlenen kriterlere göre sıralanması işleminde oluşturulan başlangıç matrisidir. Tipik bir karar matrisi $A_{1}, \ldots, A_{m}$ sıralanmak istenen alternatifleri göstermek üzere $m$ alternatiften ve $C_{1}, \ldots, C_{n}$ karar vermede kullanılacak kriterleri göstermek üzere $n$ kriterden oluşmaktadır. Her bir alternatifin sırasıyla tüm kriterlere göre değerlendirilmesiyle $\boldsymbol{X}=\left(x_{i j}\right)_{m \times n}$ karar matrisi oluşturulur.

$$
\boldsymbol{X}=\left[\begin{array}{ccc}
x_{11} & x_{12} \ldots & x_{1 n} \\
x_{21} & x_{22} \ldots & x_{2 n} \\
\vdots & \vdots & \vdots \\
x_{m 1} & x_{m 2} \cdots & x_{m n}
\end{array}\right]_{m \times n}
$$

Adım 2: Standart Karar Matrisinin (R) Olușturulması

Farklı türdeki kriterleri karşılaştırabilmek için ilk adım kriterlerin birimlerini ortadan kaldırmaktır. Bunun içinde normalizasyon işlemi uygulanarak standart karar matrisi $(R)$ oluşturulur (Denklem 7). Karar matrisindeki her bir $x_{i j}$ değeri için

$$
r_{i j}=\frac{x_{i j}}{\sqrt{\sum_{i=1}^{m} x_{i j}^{2}}}, i=1, \ldots, m, \quad j=1, \ldots, n
$$

normalizasyonu yapılarak bir $\left(r_{i j}\right)$ değeri elde edilir. Vektör normalizasyonu olarak adlandırılan bu yöntemde her bir sütun için ilgili sütunda yer alan $x_{i j}$ değerlerinin karesi alınarak sütun toplamları bulunur. Daha sonra her bir $x_{i j}$ değeri bulunduğu sütun için elde edilen bu toplamın kareköküne bölünerek normalizasyon tamamlanır ve standart karar matrisi elde edilir (Denklem 8)

$$
\boldsymbol{R}=\left[\begin{array}{ccc}
r_{11} & r_{12} \cdots & r_{1 n} \\
r_{21} & r_{22} \cdots & r_{2 n} \\
\vdots & \vdots & \vdots \\
r_{m 1} & r_{m 2} \cdots & r_{m n}
\end{array}\right]_{m \times n}
$$


Adım 3: Ağırlıklandırılmış Standart Karar Matrisinin (V) Oluşturulması

TOPSIS yönteminde kullanılan tek sübjektif parametre ağırlıklardır. $\boldsymbol{w}=\left(w_{1}, \ldots, w_{n}\right)$ vektörü $\sum_{j=1}^{n} w_{j}=1$ olacak şekilde kriter ağırlıklarını temsil etmektedir. $w_{j}$ değeri $j$. kriterin ağırlı̆̆ını göstermektedir. Standart karar matrisinin her bir kriter için belirlenen ağırlıklarla çarpılmasıyla ağırlıklandırılmış standart karar matrisi $(\boldsymbol{V})$ elde edilir. Bu durumda $V$ matrisinin elemanları $v_{i j}=$ $w_{j} r_{i j}, \quad i=1, \cdots, m, \quad j=1, \cdots, n$ değerlerinden oluşmaktadır (Denklem 9).

$$
\boldsymbol{V}=\left[\begin{array}{cccc}
w_{1} r_{11} & w_{2} r_{12} & \cdots & w_{n} r_{1 n} \\
w_{1} r_{21} & w_{2} r_{22} \cdots & w_{n} r_{2 n} \\
\vdots & \vdots & \vdots \\
w_{m} r_{m 1} & w_{m} r_{m 2} \cdots & w_{m} r_{m n}
\end{array}\right]_{m \times n}
$$

$\mathrm{Bu}$ uygulamada hibrit bir yaklaşım benimsendiğinden kriterlerin ağırlıkları sübjektif olarak doğrudan verilmeyip uzmanlar grubunun görüşlerine dayalı olarak AHP yönteminden elde edilen ağırlık değerleri kullanılmıştır.

Adım 4: Pozitif İdeal $A^{*}$ ve Negatif İdeal $\left(A^{-}\right)$Çözüm Değerlerinin Belirlenmesi

İdeal çözüm değerleri pozitif ideal çözüm $\left(A^{*}\right)$ ve negatif ideal çözüm $\left(A^{-}\right)$biçiminde gruplanabilir. $\left(A^{*}\right)$ değerleri her bir kriter incelenerek şu şekilde oluşturulur. Eğer bir kriter maksimize edilmeye çalışılan bir kriter (fayda kriteri) ise $(V)$ matrisinde bu kriterin maksimum değerinin, minimize edilmeye çalışılan bir kriter (maliyet kriteri) ise minimum değeri alınır. $I^{\prime}$ fayda kriterlerini ve $I^{\prime \prime}$ maliyet kriterlerini göstermek üzere pozitif ideal çözüm Denklem 10 da gösterilmiştir.

$$
\begin{gathered}
\boldsymbol{A}^{*}=\left\{v_{1}^{*}, v_{2}^{*}, \cdots, v_{n}^{*}\right\}=\left\{\left(\max _{j} v_{i j} \mid i \in I^{\prime}\right),\left(\min _{j} v_{i j} \mid i \in I^{\prime \prime}\right)\right\} \\
i=1,2, \cdots, m, \quad j=1, \cdots, n
\end{gathered}
$$

Benzer şekilde negatif ideal çözüm $\left(A^{-}\right)$fayda kriterleri için $(V)$ matrisindeki kriterin minimum değerinin, maliyet kriterleri için maksimum değerinin hesaplanması ile oluşturulur. Negatif ideal çözüm (Denklem 11)

$$
\begin{gathered}
\boldsymbol{A}^{-}=\left\{v_{1}^{-}, v_{2}^{-}, \cdots, v_{n}^{-}\right\}=\left\{\left(\min _{j} v_{i j} \mid i \in I^{\prime}\right),\left(\max _{j} v_{i j} \mid i \in I^{\prime \prime}\right)\right\} \\
i=1,2, \cdots, m, \quad j=1, \cdots, n
\end{gathered}
$$

şeklinde yazılabilir. Özetle, $\left(A^{*}\right)$ kümesi ağırlıklandırılmış standart karar matrisindeki en iyi performansı gösteren değerlerden, $\left(A^{-}\right)$ise en kötü performansı gösteren değerlerden oluşur.

Adım 5: Pozitif ve Negatif İdeal Noktalara Olan Uzaklı̆̆ın Hesaplanması

$\mathrm{Bu}$ adımda her bir alternatifin pozitif ideal ve negatif ideal çözümlerden sapmaları (uzaklıkları) (Denklem 12,13) hesaplanır. Bu uzaklıkların sayısı alternatif sayısı $(m)$ kadar olacaktır. Uygulamada mesafeler için Öklit uzaklığı hesaplama yaklaşımı kullanılmıştır. Buna göre Pozitif İdeal Uzaklık $\left(D_{i}^{*}\right)$ :

$$
\boldsymbol{D}_{\boldsymbol{i}}^{*}=\sqrt{\sum_{j=1}^{n}\left(v_{i j}-v_{j}^{*}\right)^{2}}, \quad i=1,2, \cdots, m, \quad j=1,2, \cdots, n
$$

Negatif İdeal Uzaklık $\left(D_{i}^{-}\right)$: 


$$
\boldsymbol{D}_{\boldsymbol{i}}^{-}=\sqrt{\sum_{j=1}^{n}\left(v_{i j}-v_{j}^{-}\right)^{2}}, \quad i=1,2, \cdots, m, \quad j=1,2, \cdots, n
$$

biçiminde hesaplanır.

Adım 6: İdeal Çözüme Göreceli Yakınlığın $\left(\boldsymbol{C}_{\boldsymbol{i}}^{*}\right)$ Hesaplanması

Önceki adımda hesaplanan $\left(\boldsymbol{D}_{\boldsymbol{i}}^{*}\right)$ ve $\left(\boldsymbol{D}_{\boldsymbol{i}}^{-}\right)$değerlerinden faydalanılarak her bir alternatifin pozitif ideal çözüme göreceli yakınlığı $\left(C_{i}^{*}\right)$ hesaplanır (Denklem 14 ).

$$
\boldsymbol{C}_{\boldsymbol{i}}^{*}=\frac{D_{i}^{-}}{D_{i}^{*}+D_{i}^{-}}, \quad i=1,2, \cdots, m
$$

Bu değer negatif ideal uzaklığın toplam uzaklığın içindeki oranını verir. Bu oran $[0,1]$ aralığında değerler alır. Bir alternatifin $C_{i}^{*}$ değeri 1 'e ne kadar yakınsa o kadar iyi bir alternatif olduğu söylenebilir. Uç durumlar için incelenecek olunursa $C_{i}^{*}=1$ olması durumunda alternatifin pozitif ideal çözüm olduğunu, $C_{i}^{*}=0$ olması ise ilgili alternatifin negatif ideal çözüm olduğunu gösterir. $C_{i}^{*}$ değerleri hesaplandıktan sonra alternatifler bu değere göre en iyiden (ideal çözüme yakınlık değeri en yüksek olandan) en kötüye doğru sıralanır (Ayçin, 2019).

\section{BULGULAR}

Çalışmada, yöntemlerin uygulanması için Microsoft Excel paket programı kullanılmıştır. AHP ve TOPSIS yöntemleri kullanılarak gerçekleştirilen analizde, öncelikli olarak dönüşüme tabi olması öngörülen ilçe ve mahallelerin deprem riski tabanında sıralanması için seçimi etkilediği düşünülen ölçütler belirlenmiştir. Bunlar;

\footnotetext{
$\checkmark$ Çok ağır hasarlı bina sayısı

$\checkmark$ Ağır hasarlı bina sayısı

$\checkmark$ Orta hasarlı bina sayısı

$\checkmark$ Can kaybı sayısı

$\checkmark$ Ağır yaralı sayısı

$\checkmark$ Doğalgaz boru hasarı sayısı

$\checkmark$ İçme suyu boru hasarı sayısı

$\checkmark$ Atık su boru hasarı sayısı
}

İlçe ve mahalle önceliklerinin seçimi ile ilgili problemin çözümü iki temel aşamadan meydana gelmiştir:

Aşama-1: Kullanılan karar ölçütleri için uzmanlardan alınan ikili karşılaştırma girdilerinin değerlendirmesi sonucu tutarlık oranı 0.089 olarak hesaplanmıştır. Bu değerin sınır değer olan 0.1'den küçük olması sayesinde kriterlerin tutarlılığı sağlandığı görülmüştür. Yapılan hesaplamalar ile her bir kriterin ağırlığı hesaplanmıştır.

Aşama-2: AHP ile elde edilmiş ağırlıklar TOPSIS yönteminde ağırlık değerleri olarak kullanılarak ilçe ve mahalle bazında öncelik sıralaması gerçekleştirilmiştir. Burada amaç, ilçelerin öncelik sıralaması ile mahalle öncelik sıralamasının karşılıklı mukayese edilebilmesidir.

AHP yöntemi ile uzman görüşlerinden elde edilen karar ölçütlerine ait ağırlıklar Tablo 5'de gösterildiği gibi hesaplanmıştır. 
Tablo 5. AHP yöntemi ile bulunan ağırlık değerleri

\begin{tabular}{|c|c|}
\hline Karar Ölçütleri & Ağırlık Değeri \\
\hline Çok ağır hasarlı bina sayısı & 0.19 \\
\hline Ağır hasarlı bina sayısı & 0.15 \\
\hline Orta hasarlı bina sayısı & 0.05 \\
\hline Can kaybı sayısı & 0.35 \\
\hline Ağır yaralı sayısı & 0.17 \\
\hline Doğalgaz boru hasarı sayısı & 0.04 \\
\hline İçme suyu boru hasarı sayısı & 0.03 \\
\hline Atık su boru hasarı sayısı & 0.02 \\
\hline Toplam & 1 \\
\hline
\end{tabular}

Ölçütlere ait ağırlık değerlerine göre; en etkili olan ölçütün \%35 ile can kaybı sayısı olduğu, çok ağır hasarlı bina sayısının \%19, ağır yaralı sayısının \%17 ve ağır hasarlı bina sayısının ise \%15 ile sıralandıkları görülmektedir. Daha az riske sahip olduğu görülen orta hasarlı bina sayısı, doğalgaz boru hattı hasarı sayısı, içme suyu boru hattı sayısı ve atık su boru hattı sayısı ölçütleri ise \%5 ve altında oranlarda belirlenmişlerdir.

Kriter ağırlıklarının AHP yöntemi ile elde edilmesinden sonra TOPSIS yöntemiyle alternatiflerin sıralanabilmesi için öncelikle karar matrisi oluşturulmuştur. Alternatiflerin belirlenen ölçütlere göre verilerinin yer aldığı bu matris oluşturulduktan sonra AHP yönteminden elde edilen ağırlıklar kullanılmak suretiyle ağırlıklı standart karar matrisi oluşturulmuştur. Tablo 6'da ağırlıklı standart karar matrisinden elde edilen ideal ve negatif ideal çözüm vektörleri gösterilmiştir.

Tablo 6. İlçeler bazında TOPSIS yönteminden elde edilen ideal $\left(A^{*}\right)$ ve negatif ideal $\left(A^{-}\right)$çözüm vektörleri

\begin{tabular}{|c|c|c|c|c|c|c|c|c|}
\hline & $\begin{array}{c}\text { Çok Ăğır } \\
\text { Hasarlı Bina }\end{array}$ & $\begin{array}{c}\text { Ağır } \\
\text { Hasarlı } \\
\text { Bina }\end{array}$ & $\begin{array}{c}\text { Orta } \\
\text { Hasarlı } \\
\text { Bina }\end{array}$ & $\begin{array}{c}\text { Can Kaybı } \\
\text { Sayısı }\end{array}$ & $\begin{array}{c}\text { Ağır } \\
\text { Yaralı } \\
\text { Sayısı }\end{array}$ & $\begin{array}{c}\text { Doğalgaz } \\
\text { Boru Hasarı }\end{array}$ & $\begin{array}{c}\text { İçme Suyu } \\
\text { Boru Hasarı }\end{array}$ & $\begin{array}{c}\text { Atık Su } \\
\text { Boru Hasarı }\end{array}$ \\
\hline $\boldsymbol{A}^{*}$ & 0.1223 & 0.1031 & 0.0187 & 0.1567 & 0.0789 & 0.0147 & 0.0108 \\
\hline $\boldsymbol{A}^{-}$ & 0.0009 & 0.0017 & 0.0015 & 0.0000 & 0.0000 & 0.0011 & 0.0007 \\
\hline
\end{tabular}

İlçe kapsamında aşama-2 için bahsedilen işlemler 971 mahalle için tekrar edilmiş ve ağırlıklı standart karar matrisinden en iyi ve en kötü değerler belirlenerek, ideal ve negatif ideal çözüm değerleri elde edilmiştir (Tablo 7).

Tablo 7. Mahalleler bazında TOPSIS yönteminden elde edilen ideal $\left(A^{*}\right)$ ve negatif ideal $\left(A^{-}\right)$çözüm vektörleri

\begin{tabular}{|c|c|c|c|c|c|c|c|c|}
\hline & $\begin{array}{c}\text { Çok Ăğır } \\
\text { Hasarlı Bina }\end{array}$ & $\begin{array}{c}\text { Ăğır } \\
\text { Hasarlı } \\
\text { Bina }\end{array}$ & $\begin{array}{c}\text { Orta } \\
\text { Hasarlı } \\
\text { Bina }\end{array}$ & $\begin{array}{c}\text { Can Kaybı } \\
\text { Sayısı }\end{array}$ & $\begin{array}{c}\text { Ăğır } \\
\text { Yaralı } \\
\text { Sayısı }\end{array}$ & $\begin{array}{c}\text { Doğalgaz } \\
\text { Boru Hasarı }\end{array}$ & $\begin{array}{c}\text { İçme Suyu } \\
\text { Boru Hasarı }\end{array}$ & $\begin{array}{c}\text { Atık Su } \\
\text { Boru Hasarı }\end{array}$ \\
\hline $\boldsymbol{A}^{*}$ & 0.0479 & 0.0472 & 0.0115 & 0.0802 & 0.0360 & 0.0072 & 0.0075 \\
\hline $\boldsymbol{A}^{-}$ & 0 & 0 & 0 & 0 & 0 & 0 & 0.0479 \\
\hline
\end{tabular}

Elde edilen çözüm vektörleri ile her bir ilçe ve mahalle için ideal ve negatif ideal çözüm setine olan uzaklıkların (sırasıyla $D_{i}^{*}$ ve $D_{i}^{-}$) belirlenmesi ile ideal çözüme olan göreceli yakınlık skorları $\left(C_{i}^{*}\right)$ hesaplanmıştır. Bu değerler Tablo 8 de yer almaktadır. 
Tablo 8. İlçeler için uzaklık ve göreceli yakınlık skorları

\begin{tabular}{|c|c|c|c|c|}
\hline Sira & İlçe & $D_{i}^{*}$ & $D_{i}^{-}$ & $C_{i}^{*}$ \\
\hline 1 & Fatih & 0,0517 & 0,2106 & 0,8028 \\
\hline 2 & Küçükçekmece & 0,0807 & 0,1837 & 0,6949 \\
\hline 3 & Bahçelievler & 0,1042 & 0,1810 & 0,6346 \\
\hline 4 & Bağcılar & 0,1181 & 0,1365 & 0,5361 \\
\hline 5 & Bakırköy & 0,1308 & 0,1214 & 0,4812 \\
\hline 6 & Esenyurt & 0,1361 & 0,1156 & 0,4593 \\
\hline 7 & Büyükçekmece & 0,1751 & 0,1101 & 0,3861 \\
\hline 8 & Güngören & 0,1697 & 0,0824 & 0,3269 \\
\hline 9 & Zeytinburnu & 0,1655 & 0,0781 & 0,3206 \\
\hline 10 & Esenler & 0,1734 & 0,0720 & 0,2934 \\
\hline 11 & Bayrampaşa & 0,1704 & 0,0692 & 0,2888 \\
\hline 12 & Beylikdüzü & 0,1841 & 0,0608 & 0,2483 \\
\hline 13 & Avcllar & 0,1870 & 0,0555 & 0,2289 \\
\hline 14 & Tuzla & 0,1937 & 0,0450 & 0,1885 \\
\hline 15 & Silivri & 0,2094 & 0,0405 & 0,1620 \\
\hline 16 & Beyoğlu & 0,2028 & 0,0356 & 0,1492 \\
\hline 17 & Pendik & 0,2074 & 0,0317 & 0,1327 \\
\hline 18 & Maltepe & 0,2081 & 0,0301 & 0,1265 \\
\hline 19 & Eyüp & 0,2099 & 0,0281 & 0,1181 \\
\hline 20 & Adalar & 0,2152 & 0,0269 & 0,1111 \\
\hline 21 & Kadıköy & 0,2141 & 0,0240 & 0,1007 \\
\hline 22 & Kartal & 0,2149 & 0,0232 & 0,0975 \\
\hline 23 & Gaziosmanpaşa & 0,2207 & 0,0174 & 0,0729 \\
\hline 24 & Üsküdar & 0.2236 & 0.0147 & 0.0616 \\
\hline 25 & Sultanbeyli & 0.2249 & 0,0144 & 0,0603 \\
\hline 26 & Ataşehir & 0,2245 & 0,0135 & 0,0567 \\
\hline 27 & Başakşehir & 0,2252 & 0,0133 & 0,0558 \\
\hline 28 & Ümraniye & 0,2283 & 0,0117 & 0,0487 \\
\hline 29 & Kağıthane & 0,2274 & 0,0105 & 0,0440 \\
\hline 30 & Beykoz & 0,2299 & 0,0094 & 0,0393 \\
\hline 31 & Sancaktepe & 0,2293 & 0,0093 & 0,0389 \\
\hline 32 & Sarıyer & 0,2302 & 0,0084 & 0,0351 \\
\hline 33 & Sultangazi & 0,2307 & 0,0071 & 0,0300 \\
\hline 34 & Şişli & 0,2308 & 0,0070 & 0,0292 \\
\hline 35 & Çatalca & 0,2342 & 0,0049 & 0,0206 \\
\hline 36 & Arnavutköy & 0,2355 & 0,0049 & 0,0205 \\
\hline 37 & Beşiktaş & 0,2335 & 0,0042 & 0,0175 \\
\hline 38 & Şile & 0,2374 & 0,0011 & 0,0048 \\
\hline 39 & Çekmeköy & 0,2373 & 0,0010 & 0,0042 \\
\hline
\end{tabular}

Tablo 8'de ilçeler ideal çözüme göreceli yakınlı̆̆ en yüksek olan Fatih ilçesinden en düşük olan Çekmeköy ilçesine doğru sıralanmıştır. Sıralama incelendiğinde, ilçeler bazında en yüksek öncelikli Fatih ilçesinin ideal çözüme en yakın (en öncelikli ilçe), aynı zamanda ideal olmayan çözüme en uzak ilçe olduğu görülmektedir. Bu ilçeyi sırayla Küçükçekmece, Bahçelievler, Bağcılar ve Bakırköy ilçeleri takip etmektedir. Son sıralarda yer alan Şile ve Çekmeköy ilçelerinin ise ideal çözüme göreceli yakınlıkları oldukça düşüktür.

Mahalleler için yapılan analiz sonucunda elde edilen uzaklık ve göreceli yakınlık skorları en öncelikli 20 mahalle için Tablo 9'da verilmiştir. 
AHP-TOPSIS Bütünleşik Yaklaşımıyla Deprem Riski Tabanlı İstanbul İli Kentsel Dönüşüm Öncelik Sıralaması

Tablo 9. Mahalleler için uzaklık ve göreceli yakınlık skorları

\begin{tabular}{|c|l|l|c|c|c|}
\hline Sıra & İlçe & Mahalle & $D_{i}^{*}$ & $D_{i}^{-}$ & $C_{i}^{*}$ \\
\hline 1 & Bakırköy & Yeşilköy & 0,0387 & 0,0816 & 0,6780 \\
\hline 2 & Bahçelievler & Şirinevler & 0,0444 & 0,0924 & 0,6753 \\
\hline 3 & Bahçelievler & Zafer & 0,0436 & 0,0861 & 0,6638 \\
\hline 4 & Bahçelievler & Siyavuşpaşa & 0,0484 & 0,0874 & 0,6434 \\
\hline 5 & Bahçelievler & Bahçelievler & 0,0517 & 0,0743 & 0,5898 \\
\hline 6 & Bahçelievler & Soğanli & 0,0534 & 0,0751 & 0,5847 \\
\hline 7 & Küçükçekmece & Kanarya & 0,0508 & 0,0654 & 0,5626 \\
\hline 8 & Küçükçekmece & Cumhuriyet & 0,0517 & 0,0652 & 0,5576 \\
\hline 9 & Bakırköy & Kartaltepe & 0,0555 & 0,0672 & 0,5480 \\
\hline 10 & Küçükçekmece & İnönü & 0,0530 & 0,0625 & 0,5411 \\
\hline 11 & Bahçelievler & Kocasinan Merkez & 0,0588 & 0,0607 & 0,5083 \\
\hline 12 & Fatih & Yedikule & 0,0578 & 0,0593 & 0,5064 \\
\hline 13 & Fatih & KocaMustafapaşa & 0,0582 & 0,0580 & 0,4994 \\
\hline 14 & Bakırköy & Şenlikköy & 0,0574 & 0,0564 & 0,4956 \\
\hline 15 & Küçükçekmece & Cennet & 0,0621 & 0,0556 & 0,4724 \\
\hline 16 & Bahçelievler & Yenibosna Merkez & 0,0683 & 0,0579 & 0,4588 \\
\hline 17 & Bahçelievler & Hürriyet & 0,0673 & 0,0515 & 0,4335 \\
\hline 18 & Bayrampaşa & Yildirim & 0,0660 & 0,0485 & 0,4235 \\
\hline 19 & Küçükçekmece & Tevfikbey & 0,0670 & 0,0470 & 0,4124 \\
\hline 20 & Bağcllar & Evren & 0,0689 & 0,0468 & 0,4043 \\
\hline
\end{tabular}

Tablo 9'da mahalleler ideal çözüme göreceli yakınlı̆̆ı en düşük Bakırköy ilçesi Yeşilköy mahallesinden başlanarak sıralanmıştır. İlk 20 mahalle dikkate alındığında, ilçeler sıralamasında ilk 5 içerisinde yer alan Fatih, Küçükçekmece, Bahçelievler, Bağcılar ve Bakırköy ilçelerinin yine yüksek önceliğe sahip oldukları anlaşılmaktadır. Yani mahalle sıralaması ilçe sıralamasını bir bakıma doğrular niteliktedir.

Şekil 1'de öncelik sıralamasında ilk 100 mahallenin ilçelere göre dağllımları verilmiştir. Şekil değerlendirildiğinde, mahalle dağılımının yine ilçe sıralamasında yer alan ilk 5 ilçede yoğunlaştığı görülmektedir. Diğer mahalleler ise ilçe sıralamasında düzensiz olarak dağılmışlardır.

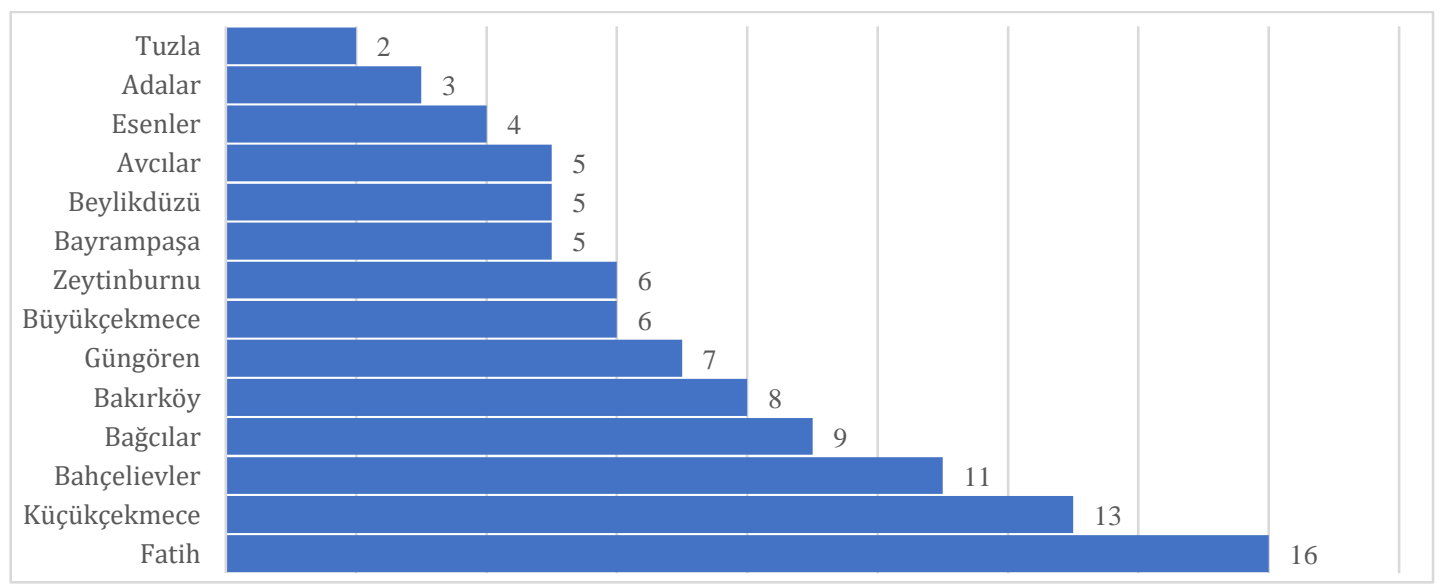

Şekil 1. Mahalle öncelik sıralamasında ilk 100 mahallenin ilçelere göre dağılımı 


\section{SONUÇ VE ÖNERILER}

Türkiye'de büyük kentlere 1950'li yıllardan itibaren artan göç ile ortaya çıkan yasadışı ve düzensiz yapılașma sonucu, yapı stokunun kalitesiz ve ekonomik ömrünü tamamlamıș olması, afet riski karşısında son derece önemli bir toplumsal problem teşkil etmektedir. Eskimiş, yıpranmış ve sağlıksız yaşam alanlarının, deprem tehlikesi karşısında büyük can ve mal kaybı riski altında olan șehirlerin kentsel dönüşüm ile yenilenmesi en öncelikli gündem konusudur. Deprem riski altındaki İstanbul ili, yüksek nüfusu ve ekonomik hayata olan etkisi sebebiyle kentsel dönüşümün odak noktasıdır. Ancak, kentsel dönüşüm planlama süresi, mevcut yaşayan halkın ikna edilmesi ve tahliyesi zorluklarıyla birlikte yüksek maliyetli projelerdir. Riskli alanların eș zamanlı olarak dönüşümüne başlanması bu anlamda mümkün olmamaktadır. Dolayısıyla en riskli olandan daha az riskli olan alanlara olacak şekilde dönüşümün planlanarak projelerin uygulanması doğru bir yaklaşım olacaktır.

Bu çalışmada, İstanbul ili sınırlarında yer alan 39 ilçe ve 971 mahallenin kentsel dönüşüm önceliklendirme sıralaması AHP-TOPSIS bütünleșik yaklaşımı ile oluşturulmuştur. Kullanılan karar ölçütleri uzmanlardan mülakat yoluyla alınmış ve AHP yöntemi ile ölçütlerin ağırlıkları, TOPSIS yöntemi ile de bu ağırlıklar kullanılarak ilçe ve mahalle bazında öncelik sıralaması yapılmıştır. Elde edilen sonuçlara göre, dönüşüm sıralaması için ilçe bazlı bir yaklaşım yeterli olmayacaktır. Çünkü riski yüksek çıkan ilçelerin her mahallesi eşit oranda riske sahip olmadığından, mahalle bazlı bir öncelik sıralaması kentsel dönüşüm projeleri için uygun olacaktır. Örneğin, en riskli görülen Fatih ilçesinin en riskli ilk 100 mahalle sıralamasında 16 mahallesi bulunurken, ikinci sırada yer alan Küçükçekmece ilçesinin 13 mahallesi ilk 100 sıralamasında yer almıştır. Benzeri durumlar diğer ilçeler içinde söz konusudur. Yüksek çoğunlukta risk sıralamasında üstlerde yer alan ilçelerin mahalleleri riskli bulunsa da dönüşüm projeleri her ilçenin en riskli mahallelerinin eş zamanlı projeler ile dönüştürülmesi ya da ilçe ayrımı yapılmadan mahalle önceliklerine göre kentsel dönüşümün gerçekleştirilmesi çözüm olabilecektir. Sonuç olarak bu çalışmada ortaya çıkan veriler ışığında, yetkili kamu kurum ve kuruluşları ile ilgili diğer işletmelere, kentsel dönüşüm projelerinin uygun şartlarda hangi alanlardan başlanması konusunda önemli bir bilgi sunacağı düşünülmektedir. Ayrıca çalışma, gelecekte konu hakkında yapılacak benzeri çalışmalara projeksiyon sağlayacaktır.

\section{KAYNAKLAR}

Akgün, İ. ve Erdal, H. (2019). Solving an Ammunition Distribution Network Design Problem Using MultiObjective Mathematical Modeling, Combined AHP-TOPSIS and GIS, Computers and Industrial Engineering, 129: 512-528.

Akkar, Z.M. (2006). Kentsel Dönüşüm Üzerine: Batıdaki Kavramlar, Tanımlar, Süreçler ve Türkiye, Planlama, 2:29-38.

Alaybeyoğlu, A., Kılıç, U., İregöl, A. ve Konbul, Y. (2016). Kentsel Dönüşümde Mahalleler Arası Öncelik Sıralaması: Örnek Bir Karar Destek Sistemi, Uludağ Üniversitesi Mühendislik Fakültesi Dergisi, 21(2): 377 402.

Alkan, T. ve Durduran, S. (2020). Konut Seçimi Sürecinin AHP Temelli TOPSIS Yöntemi ile Analizi, Necmettin Erbakan Üniversitesi Fen ve Mühendislik Bilimleri Dergisi, 2(2):12-21.

Alonso, J. A. ve Lamata, M. T. (2006). Consistency in the Analytic Hierarchy Process: A New Approach, International Journal of Uncertainty, Fuzziness and Knowledge-Based Systems, 14: 445-459.

Alterman, R. ve Cars, G. (1991). Neighborhood Regeneration: An International Evaluation, London:Mansell Publication. 
Arslan, A.E., Arslan, O. ve Kandemir, S. Y. (2020). AHP-TOPSIS Hybrid Decision-Making Analysis: Simav İntegrated System Case Study, Journal of Thermal Analysis and Calorimetry, 1-12, doi: https://doi.org/10.1007/s10973-020-10270-4.

Ataöv, A. ve Osmay, S. (2007). Türkiye'de Kentsel Dönüşüme Yöntemsel Bir Yaklaşım, ODTÜ Mimarlık Fakültesi Dergisi, 57-82.

Ayçin, E. (2019). Çok Kriterli Karar Verme-Bilgisayar Uygulamalı Çözümler, Ankara: Nobel Akademik Yayıncılık.

Balaban, O. (2013). Neoliberal Yeniden Yapılanmanın Türkiye Kentleşmesine Bir Diğer Armağanı: Kentsel Dönüşümde Güncelin Gerisinde Kalmak. (Çavdar A. ve Tan P., Ed.). İstanbul: Müstesna Şehrin İstisna Hali :51-80. İstanbul: Sel Yayıncılık.

Demirkol, İ. (2021). Sustainable Supply Chain: A Gradation Model That Based on AHP-TOPSIS Method, Atatürk Üniversitesi İktisadi ve İdari Bilimler Dergisi, 35(2):595-618, doi: https://doi.org/10.16951/atauniiibd.799045.

DEZIM (2020). İBB Deprem Risk Yönetimi ve Kentsel İyileştirme Daire Başkanlığl, Deprem ve Zemin İnceleme Müdürlügü (DEZİM) İstanbul İli Olası Deprem Kayıp Tahminleri Kitapçı̆̆ı, https://depremzemin.ibb.istanbul/guncelcalismalarimiz/, (Son Erişim Tarihi: 21 Ocak 2021).

Donnison, D. (1993). The Challenge of Urban Regeneration for Community Development, Community Development Journal, 28(4): 293-298.

Genç, F. N. (2008). Türkiye'de Kentsel Dönüşüm: Mevzuat ve Uygulamaların Genel Görünümü, Celal Bayar Üniversitesi İ.İ.B.F Dergisi, 15(1): 115-130.

Gürbüz, A. ve Tekin, M. (2015). Performans Sıralaması Yöntemiyle Mevcut Binaların Bölgesel Deprem Risk Dağılımının Belirlenmesi, Celal Bayar University Journal of Science, 11(1): 37-48.

Gürkan, S. (2021). TOPSIS Çok Kriterli Karar Verme Yöntemi İle Karşılaştırmalı Finansal Performans Analizi: Teknoloji Şirketleri Üzerine Bir Araştırma, Finans Ekonomi ve Sosyal

Araştırmalar Dergisi, 6(2):225-239. doi: https://doi.org/10.29106/fesa.868905.

Hwang, C.-L. ve Yoon, K. (1981). Methods for Multiple Attribute Decision Making. (C.-L. Hwang ve K. Yoon, Ed.) Lecture Notes in Economics and Mathematical Systems. Berlin, Heidelberg: Springer. doi:10.1007/9783-642-48318-9_3.

İpek, Ç ve Şahin, Y. (2019). AHP Temelli Gri İlişkisel Analiz Yöntemi ile Konut Seçimi, Gümüşhane Üniversitesi Sosyal Bilimler Enstitüsü Elektronik Dergisi, 9(25): 153-172.

Jena, R. ve Pradhan, B. (2020). Integrated ANN-Cross-Validation and AHP-TOPSIS Model to İmprove Earthquake Risk Assessment, International Journal of Disaster Risk Reduction, 50: 1-16, doi:http:// doi:10.1016/j.ijdrr.2020.101723.

Jena, R., Pradhan, B., Beydoun, G., Ardiansyah, N., Sofyan, H. ve Affan, M. (2020). Integrated Model For Earthquake Risk Assessment Using Neural Network and Analytic Hierarchy Process: Aceh Province, Indonesia, Geoscience Frontiers, 11(2):613-634, doi.org/10.1016/j.gsf.2019.07.006.

Jena, R., Pradhan, B., Naik, S.P. ve Alamri, A.M. (2021). Earthquake Risk Assessment İn NE India Using Deep Learning And Geospatial Analysis, Geoscience Frontiers, 12(3), doi: http://doi.org/10.1016/j.gsf.2020.11.007.

Keleş, R. (2004). Kentsel Dönüşümün Tüzel Altyapısı, Mimarist Dergisi, TMMOB Mimarlar Odası İstanbul Büyükkent Şubesi, 4(12):73-75. 
Kwiesielewicz, M. ve van Uden, E. (2004). Inconsistent And Contradictory Judgements in Pairwise Comparison Method in the AHP, Computers and Operations Research, 31(5): 713-719. doi: http://10.1016/S0305-0548(03)00022-4.

Lichfield, D. (1992). Urban Regeneration for the 1990’s, London: London Planning Advisory Committee.

Mahmoudi, M., Aydi, A. ve İbrahim, H. (2021). Site Selection for Artificial Recharge with Treated Wastewater with The İntegration of Multi-Criteria Evaluation and ELECTRE III, Environmental Science and Pollution Research, doi: https://doi.org/10.1007/s11356-021-12354-6.

Oztaysi, B., Cevik O.S. ve Kahraman, C. (2016). Fuzzy Multicriteria Prioritization of Urban Transformation Projects for Istanbul, 30(4): $2459-2474$.

Özbek, A. (2009). Çok Kriterli Karar Verme Yöntemleri ve Excel ile Problem Çözümü, İkinci Basım, Ankara: Seçkin Yayınları.

Özdemir, M. (2014). TOPSIS. (Yıldırım B.F. ve Önder E. Ed.) Çok Kriterli Karar Verme Yöntemleri, Bursa: Dora Yayınları.

Panwar, N., Kumar ve S., Attri, R. (2020). AHP-VIKOR-based Methodology For Determining Maintenance Criticality, International Journal of Productivity and Quality Management, 29(2):167-186.

Papathanasiou, J. ve Ploskas, N. (2018). Multiple Criteria Decision Aid: Methods, Examples and Python Implementations, Springer International Publishing.

Peng, Y., Lai, Y., Li, X. ve Zhang, X. (2015). An Alternative Model For Measuring The Sustainability Of Urban Regeneration: The Way Forward, Journal of Cleaner Production, 109: 76-83, doi: https://10.1016/j.jclepro.2015.06.143.

Ridha, H. M., Gomes, C., Hizam, H., Ahmadipour, M., Muhsen, D. H. ve Ethaib, S. (2020). Optimum Design of a Standalone Solar Photovoltaic System Based on Novel Integration of Iterative-PESA-II and AHP-VIKOR Methods, Processes, 8(3):367-382.

Roberts, P. ve Sykes, H. (2000). Urban Regeneration: A Handbook, SAGE Publications, doi: http://dx.doi.org/10.4135/9781446219980.

Roberts, P. ve Sykes, H. (2017). Urban Regeneration: A Handbook, SAGE Publications Ltd; 2nd edition, doi: http://dx.doi.org/10.4135/9781473921788.

Saaty, T. (1980). The Analytic Hierarchy Process, New York:McGraw-Hill,.

Saaty, T. (1977). A Scaling Method For Priorities İn Hierarchical Structures, Journal of Mathematical Psychology, 15(3): 234-281.

Sadioğlu, U. ve Ergönül, E. (2020). Türkiye'de Kentsel Dönüşümün Anlamı, Aktörleri ve Amaçları, İdealkent, 11(30): 878-908.

Safari, A., Abbaspour, M. ve Javid, A. H. (2020). The Application of Multi-Criteria (AHP-PROMETHEE) Decision-Making Methods in Selecting and Prioritizing The Green Area İrigation Resources, International Journal of Environmental Science and Technology, doi: https://doi.org/10.1007/s13762-020-02875-x.

Sanders, D. A., Ikwan, F. ve Haddad, M. (2020). A Combined AHP-PROMETHEE Approach for Intelligent Risk Prediction of Leak in a Storage Tank, International Journal of Reliability, Risk and Safety: Theory and Application, 3(2):55-61.

Sharma, V., Meena, M. L., Kumar, M. ve Patnaik, A., 2020, Optimization of Waste Fly Ash Powder Filled Glass Fiber Reinforced Epoxy Composite by Hybrid AHP-TOPSIS Approach, Materials Today: Proceedings, doi: https://doi.org/10.1016/j.matpr.2020.11.394. 
Timor, M. (2010). Yöneylem Araştırması, İstanbul: Türkmen Kitapevi.

Tümtürk, A. ve Tümtürk, E. (2020). Kritik Yol Metodu ile Kentsel Dönüşüm Bina Projelerinin Programlanması: İzmir Karşıyaka Örneği, Dumlupınar Üniversitesi Sosyal Bilimler Dergisi, 63:175-190.

Varol, N. ve Gültekin, T. (2016). Afet Antropolojisi, Elektronik Sosyal Bilimler Dergisi, 15(59): 1431-1436.

Vural, D. ve Kose, E. (2020). Selection of Alternative Filling Material in the Bed Production with AHP And ELECTRE Methods, Journal of Applied Research on Industrial Engineering, 7(2):163-176.

Wang, L., Ali, Y., Nazir, S. ve Niazi, M. (2020). ISA Evaluation Framework for Security of Internet of Health Things System Using AHP-TOPSIS Methods. IEEE Access, 8:152316-152332, doi: https://doi.org/10.1109/ACCESS.2020.3017221.

Yariyan, P., Zabihi, H., Wolf, Isabelle D., Karami, M. ve Amiriyan, S. (2020). Earthquake Risk Assessment Using an İntegrated Fuzzy Analytic Hierarchy Process with Artificial Neural Networks Based on GIS: A Case Study Of Sanandaj İn Iran, International Journal of Disaster Risk Reduction,50, doi: http.//doi.org/10.1016/j.ijdrr.2020.101705.

Yıldız, S., Kıvrak, S. ve Arslan, G. (2017). A Model Proposal For Sustainable Urban Transformation, International Journal of Innovation, Management and Technology, 8(6):440-446.

Yılmaz, A. (2003). Türk Kamu Yönetiminin Sorun Alanlarından Biri Olarak Afet Yönetimi, Ankara: Pegem A Yayıncilık.

Zhu, S., Li, D. ve Jiang, Y. (2020). The Impacts of Relationships Between Critical Barriers on Sustainable Old Residential Neighborhood Renewal in China, Habitat International, 103, doi:http:// doi.org/10.1016/j.habitatint.2020.102232.

Zhu, S., Li, D., Feng, H., Gu, T. ve Zhu, J. (2019). AHP-TOPSIS-Based Evaluation of the Relative Performance of Multiple Neighborhood Renewal Projects: A Case Study in Nanjing, China, Sustainability, MDPI Open Access Journal, 11(17):1-17.

\section{EKLER}

Ek A: İlçeler bazında karar kriterleri verileri

\begin{tabular}{|c|c|c|c|c|c|c|c|c|}
\hline \multirow[b]{2}{*}{ İlçe } & \multicolumn{3}{|c|}{ BİNA YAPISI } & \multicolumn{2}{|c|}{ CAN KAYBI/ YARALANMA } & \multicolumn{3}{|c|}{ ALTYAPI } \\
\hline & $\begin{array}{l}\text { Çok Ağır } \\
\text { Hasarlı }\end{array}$ & $\begin{array}{c}\text { Ağır } \\
\text { Hasarlı }\end{array}$ & $\begin{array}{c}\text { Orta } \\
\text { Hasarlı }\end{array}$ & $\begin{array}{c}\text { Can Kaybı } \\
\text { Sayısı }\end{array}$ & $\begin{array}{l}\text { Ağır Yaralı } \\
\text { Sayısı }\end{array}$ & $\begin{array}{c}\text { Doğalgaz } \\
\text { Boru Hasarı }\end{array}$ & $\begin{array}{c}\text { İçme Suyu } \\
\text { Boru } \\
\text { Hasarı }\end{array}$ & $\begin{array}{c}\text { Atık Su } \\
\text { Boru } \\
\text { Hasarı }\end{array}$ \\
\hline Adalar & 413 & 743 & 1894 & 76 & 61 & 3 & 5 & 8 \\
\hline Arnavutköy & 41 & 243 & 1704 & 0 & 0 & 7 & 9 & 17 \\
\hline Ataşehir & 123 & 471 & 2756 & 89 & 47 & 6 & 7 & 18 \\
\hline Avcilar & 233 & 1261 & 5545 & 465 & 239 & 19 & 22 & 54 \\
\hline Bağcılar & 796 & 1825 & 8001 & 1179 & 652 & 16 & 20 & 52 \\
\hline Bahçelievler & 796 & 2090 & 5668 & 1633 & 879 & 17 & 21 & 52 \\
\hline Bakırköy & 782 & 1306 & 3394 & 1046 & 581 & 15 & 17 & 48 \\
\hline Başakșehir & 115 & 575 & 3045 & 71 & 45 & 6 & 9 & 20 \\
\hline Bayrampaşa & 614 & 1182 & 4059 & 520 & 340 & 5 & 8 & 19 \\
\hline Beşiktaş & 64 & 187 & 1053 & 26 & 14 & 2 & 2 & 6 \\
\hline Beykoz & 113 & 443 & 2756 & 25 & 16 & 6 & 6 & 13 \\
\hline Beylikdüzü & 261 & 950 & 3004 & 527 & 276 & 21 & 32 & 72 \\
\hline Beyoğlu & 410 & 840 & 3132 & 217 & 150 & 3 & 5 & 12 \\
\hline
\end{tabular}


Afet ve Risk Dergisi Cilt: 4 Sayı: 2, 2021 (203-223)

Furkan DISŞKAYA, Şenol EMİR

\begin{tabular}{|c|c|c|c|c|c|c|c|c|}
\hline Büyükçekmece & 439 & 6622 & 1635 & 288 & 154 & 26 & 33 & 54 \\
\hline Çatalca & 63 & 301 & 1656 & 4 & 2 & 4 & 7 & 13 \\
\hline Çekmeköy & 16 & 113 & 998 & 1 & 0 & 3 & 4 & 7 \\
\hline Esenler & 391 & 813 & 3739 & 638 & 352 & 6 & 7 & 20 \\
\hline Esenyurt & 563 & 1768 & 7911 & 1003 & 553 & 24 & 29 & 63 \\
\hline Eyüp & 300 & 841 & 3794 & 168 & 110 & 6 & 9 & 20 \\
\hline Fatih & 2083 & 3496 & 9949 & 1484 & 985 & 11 & 18 & 43 \\
\hline Gaziosmanpaşa & 132 & 403 & 2276 & 140 & 83 & 3 & 4 & 10 \\
\hline Güngören & 342 & 611 & 2407 & 754 & 415 & 7 & 9 & 24 \\
\hline Kadıköy & 209 & 505 & 2426 & 190 & 93 & 6 & 8 & 18 \\
\hline Kağıthane & 94 & 275 & 1727 & 84 & 44 & 3 & 4 & 10 \\
\hline Kartal & 195 & 593 & 3282 & 176 & 87 & 7 & 8 & 22 \\
\hline Küçükçekmece & 1240 & 2616 & 8978 & 1515 & 925 & 21 & 25 & 61 \\
\hline Maltepe & 237 & 690 & 3388 & 234 & 130 & 8 & 10 & 22 \\
\hline Pendik & 274 & 1041 & 5625 & 195 & 101 & 13 & 16 & 35 \\
\hline Sancaktepe & 84 & 416 & 2539 & 48 & 24 & 6 & 8 & 19 \\
\hline Sarıyer & 102 & 367 & 2486 & 33 & 21 & 5 & 6 & 11 \\
\hline Şile & 16 & 107 & 772 & 0 & 0 & 3 & 5 & 6 \\
\hline Silivri & 444 & 1707 & 7153 & 58 & 28 & 21 & 30 & 36 \\
\hline Şiş̧li & 69 & 208 & 1009 & 58 & 28 & 2 & 2 & 5 \\
\hline Sultanbeyli & 108 & 648 & 3950 & 73 & 38 & 6 & 10 & 21 \\
\hline Sultangazi & 62 & 245 & 1804 & 57 & 26 & 3 & 2 & 13 \\
\hline Tuzla & 446 & 1370 & 5310 & 266 & 169 & 14 & 19 & 48 \\
\hline Ümraniye & 105 & 536 & 3626 & 42 & 17 & 7 & 10 & 23 \\
\hline Üsküdar & 146 & 493 & 3341 & 92 & 42 & 6 & 7 & 15 \\
\hline Zeytinburnu & 510 & 1025 & 3799 & 668 & 372 & 8 & 11 & 30 \\
\hline
\end{tabular}

Kaynak: https://depremzemin.ibb.istanbul/guncelcalismalarimiz/ (21.01.2021) 